\title{
الاتجاهات العالمية المعاصرة في تدويل التعليم العالي دراسة تحليلية وصفية
}

\author{
| اعـداد \\ د.عصام جمال سليم غانم \\ مدرس بقسم تقويم الموارد الطيعية \\ معهل الدراسات والبحوث البيئة جامعة مدينة السادات
}

Doi : 10.12816/0051209

مجلة الدراسات التربوية والانسانية ـ كلية التربية ـ جامعة دمنهور .

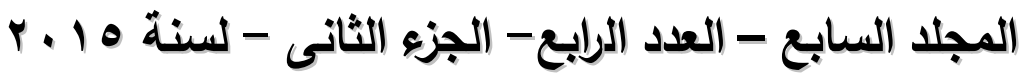


الاتجاهات العالمية المعاصرة في تدويل التعليم العالي دراسة تحليلية وصفية د.عصام جمال سليم غانم 


\section{الاتجاهات العالمية المعاصرة في تدويل التعليم العالي دراسة تحليلية وصفية}

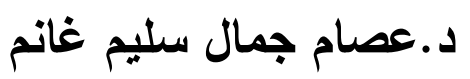

\section{ملخص البحث}

هدف هذا البحث إلى تقديم مفهوم تدويل التعليم وطبيعته، وعرض

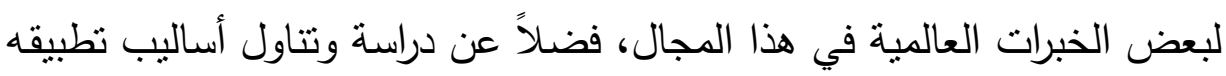
في مؤسسـات التعليم العالي العربية وذلك بهدف دعم الجهود المبذولـة لتدويل مؤسسات التعليم العالي في ضوء الخبرات العالمية. ولتحقيق هذه الأهداف استتد

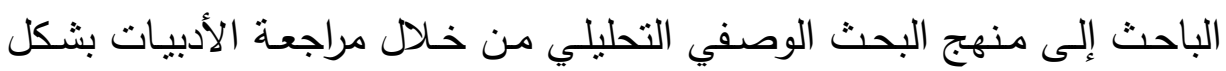

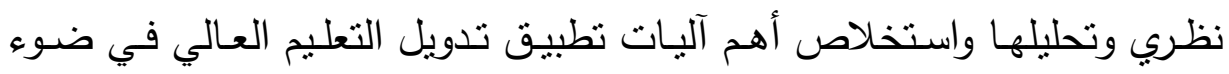

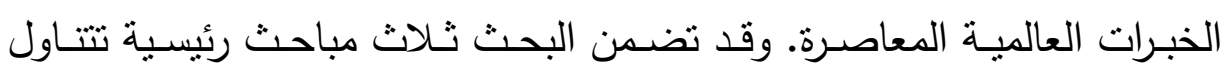
مفهوم وطبيعـة تدويل التعليم وتطبيقاته، أمتلـة للخبرات العالمية فيه. وقد اختنت الباحث البحث بمجموعة دن التوصيات الهادفة إلى تفعيل تطبيق تدويل التعليم

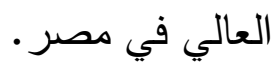


الاتجاهات العالمية المعاصرة في تدويل التعليم العالي دراسة تحليلية وصفية د.عصام جمال سليم غانم

Abstract 


\section{مقدمة:}

كـان لظـاهرة العولمـة التـي يعيشـها عالمنـا المعاصـر منـذ عقود العديد مـن التداعيات العميقة على المستويات الاجتماعية، والسياسية، والاقتصـادية، والتي غيرت معالم العديد من الممارسات المتبعة وأفرزت ممارسات وآليات جديدة. ولم والم يكن المجال التعليمي بمنآي عن هذه التغييرات العميقة التي تسببت فيها العولمة. ويشمل مفهوم العولمة عدة مجالات حياتية مختلفة من قبيل التجارة وعالم المال

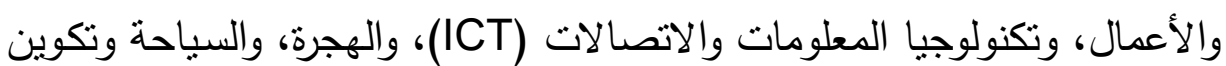

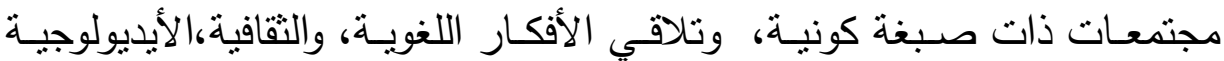
المختلفة (Magrath, 2000). وتبرز تجليات العولمة بالنسبة لعمليات التدريس والتعلم داخل مؤسسات التعليم العالي في عدد من القضـايا الهامـة من قبيل التعليم المتعدد الثقافات، والوعي بالهوية والذاتية الثقافية، والنزعة التعددية في التفكير ، والمواطنة الكونية، مما كان هنالك اهتمـام كبير في مؤسسـات التعليم العـالي بمضـامين العديج من القضـايا الرئيسية بالنسبة للتعليم والمنهج الدراسي مثل العولمـة، وتكافؤ الفرص، والمساواة الاجتماعية، والتتوع، والتعددية الثقافية(Sutton, 2005; UNESCO,1998). وكان بان من أبرز تأثثرات العولمة في هذا السياق، دعم الاتجاه نحو تدويل التعليم.

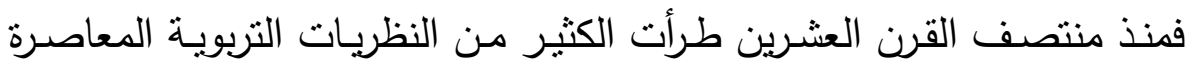
التي شجعت على التبادل العلمي، وبناء قاعدة تعليمية دولية تسهم في تطوير ،

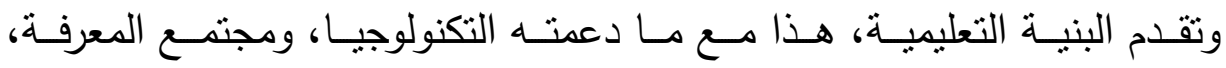

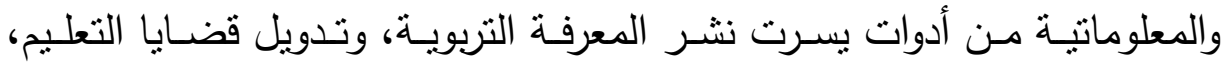
ومنتجاته المادية في صورة برامج تعليمية، وخدمات، ومنح تعليمية، وبشرية من

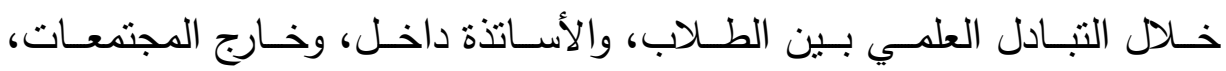
بالإضـافة إلـى المشـروعات التعليميـة الدوليـة، وبرتوكـولات الثــراكة فـي بنـاء

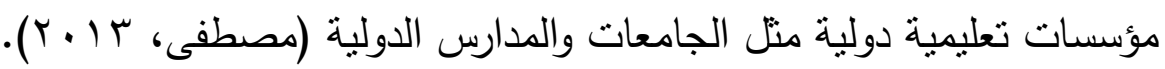


ويمكن التعرف على أهم معالم تدويل التعليم العالي، من خلال كل من

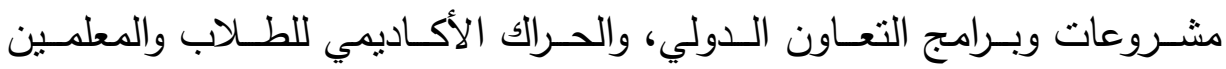
والباحثين، وتطوير برامج وأنشطة للتعليم العالي ذات طابع دولي (محمود، ....؟، ص صTV)

وتمثل زيادة وتيرة وسرعة تدويل مؤسسات التعليم العالي في جوهره استجابة

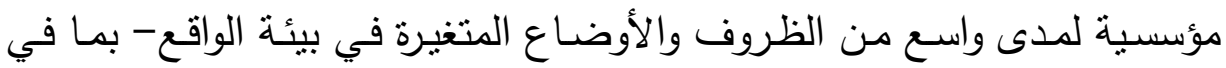

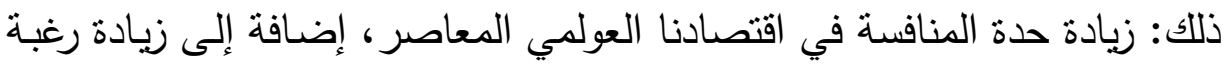

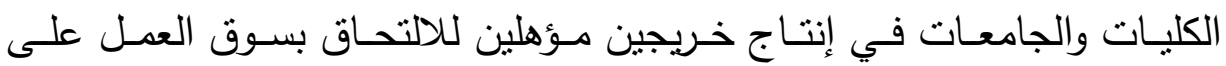
المستوى الدولي. وحالياً ونحن في بدايات القرن الحادي والعشرين، بدأ "إضفاء

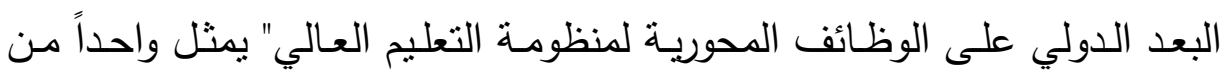

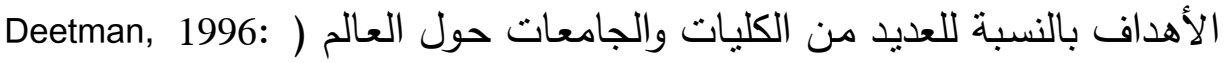

وعلى الرغم مما يترتب على العولمة من تحديات، فإنها توفر - أيضاً - فرصاً

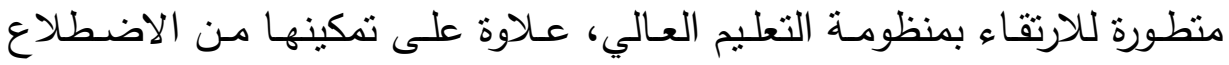
بلعب دور أساسي في تشكيل معالم المستقبل (Cornwell, 2001).

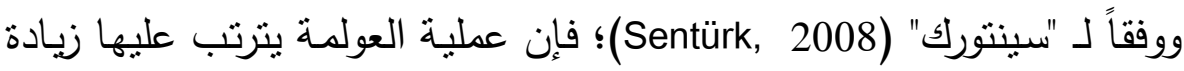
حجم المسئوليات الملقاة على كاهل دول العالم فيما يتعلق بالتركيز على قضية

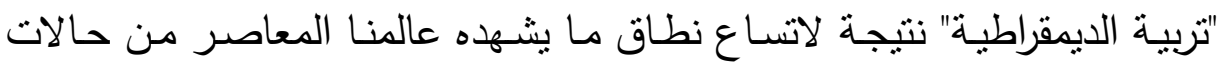

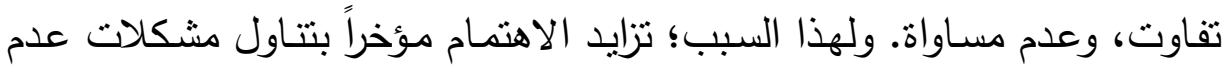
تكافؤ الفرص التعليميـة، وعدم العدالـة والمسـاواة في الالتحساق بـالتعليم. ولهـذا السبب؛؛ بـدأت مؤسسـات التعليم العـالي في تصـيميم عمليـات التدريس والتتعلم كمجالات خدمية ذات صبغة دولية تهنت في الوقت نفسه بالوفاء بمعايير المنافسـة

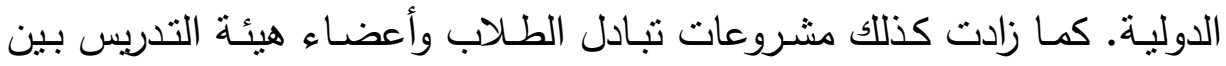
الجامعات على المستوى الدولي. وفي خضـم هذه العمليـة، ازداد اتسـاع نطـاق هلئ 
تطبيقات ما يلي في عمليات التدريس والتعلم على الصعيد الدولي: التعليم عن بعد، والتعليم الإكتروني والجوال، وجهود ومبادرات التطوير التعليهي، والتقنين القياسي، والوفاء بمعايير مقننة ومرتفعة المستوى عالمياً، الخ (Huang, 2007).

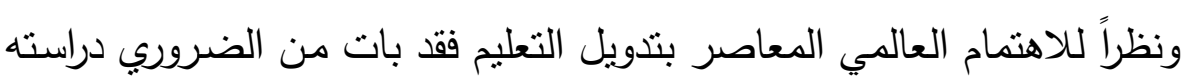

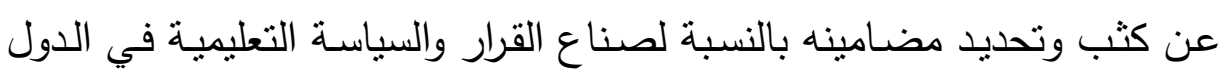

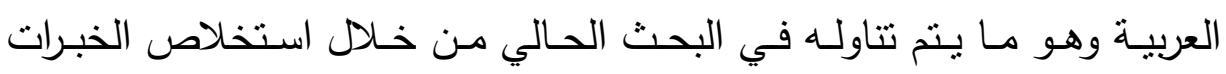
العالمية المعاصرة وماضمينها في هذا المجال.

\section{مشكلة البحث وتساؤلاته:}

تفرض العولمة ومتغيراتها مجموعـة من التحديات والمتطلبات التي يتعين

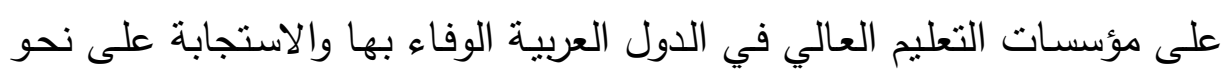

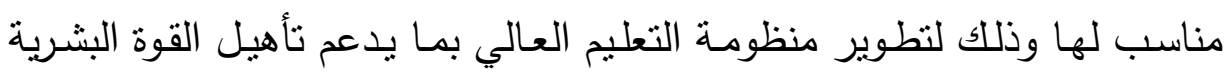
اللازمة للاستجابة لمتطلبات للعولمة.

ففي الوقت الراهن، أصبحت مؤسسات التعليم العالي حول العالم تعتبر التدويل واحداً من أبرز أولوياتها للوفاء باحتباجات الحاضر ، ومواجهة تحديات المستقبل هونيل

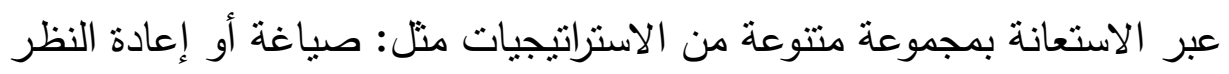

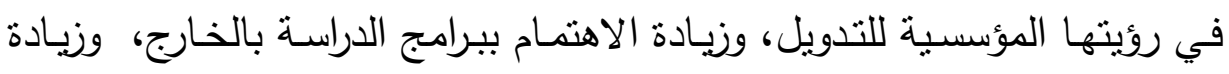

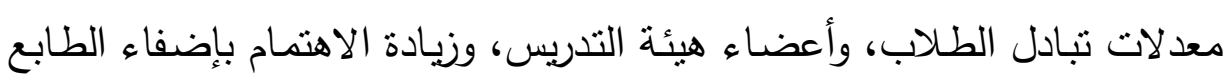

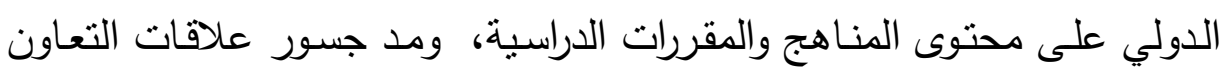
والثراكة مع المؤسسات الأكاديمية في الخارج (Callan, 2000).

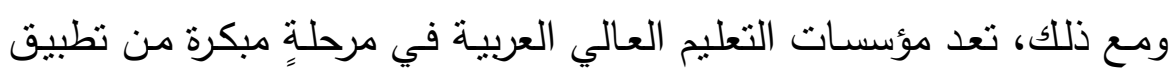

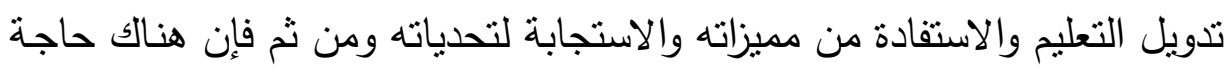

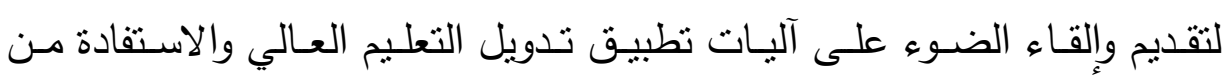
الخبرات العالمية المعاصرة في هذا المجال. وفي حدودعلم الباحث فان مفهوم 
تدويل مؤسسات التعليم العالي لم يحظي بالدراسة في البيئة العربية، كما انه يعتبر

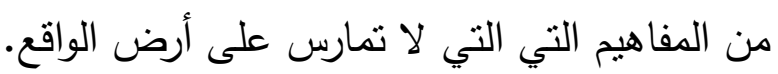

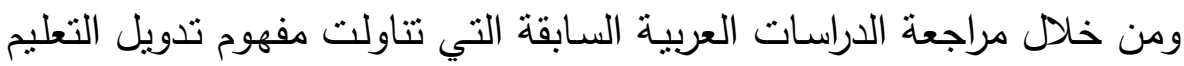

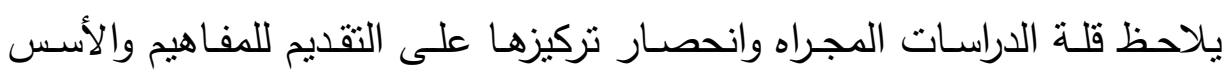

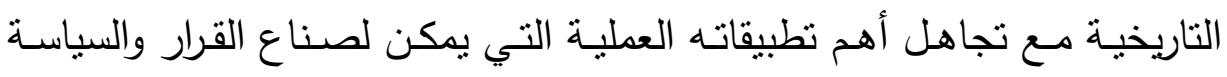

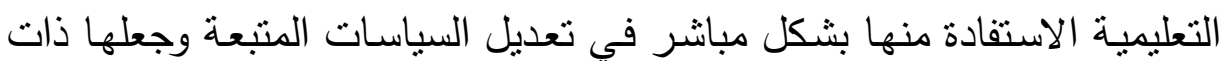
طبيعية دولية أكثر .

ومـن خـلال عمل الباحث يرحب أعضــاء هيئة التدريس بأحدي الجامعـات

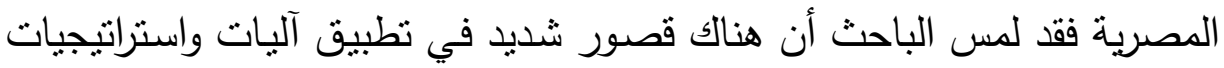

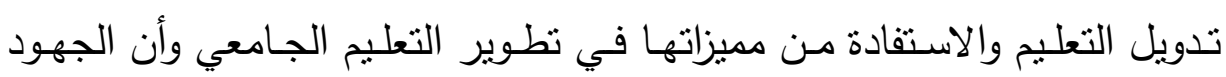

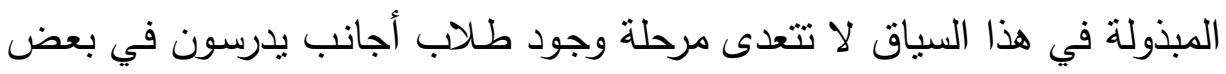
الجامعات المصرية وهو ما يعد مستولى أولى في تطبيق تدويل التعليم العالي.

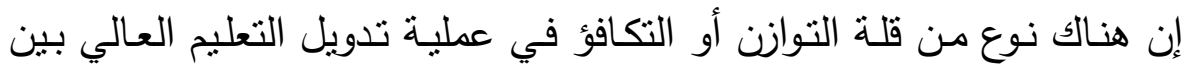

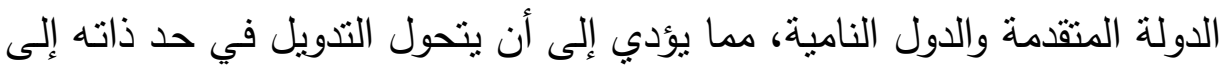

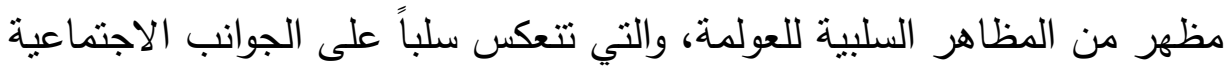

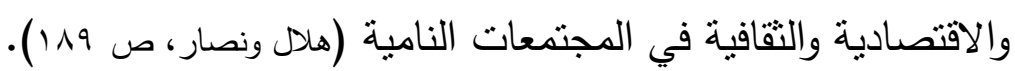
واستتاداً إلى ما تقدم الباحث يرى من الضروري - سواءً من الناحية النظرية أو صائه

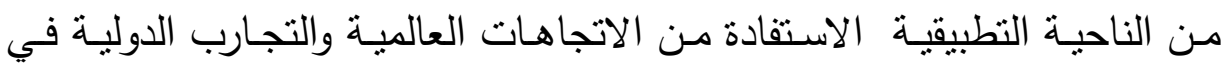
مجال تدويل التعليم واستخلاص أهم آليات تطبيـق تدويل التعليم وتفعيله في الهي مؤسسات التعليم العالي وذللك لنطوير مؤسسات التعليم العالي المصرية وهو ما يتم تتاوله في البحث الحالي. واستتاداً إلى ذلك فإنه يمكن التعبير عن مشكلة هذاب

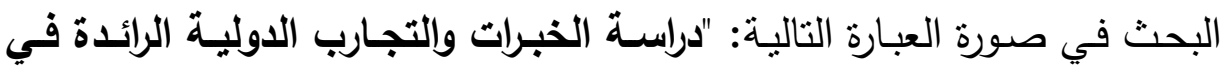
مجال تدويل التعليم، والاستفادة منها في تحديد مداخل واستراتيجيات ومراحل تطبيق تدويل التعليم بالجامعات مؤسسات التعليم العالي المصرية". 
ويمكن التعبير عن هذه المشكلة في صورة التساؤلات التالية:

$$
\text { (1) (1) مفهوم وأبعاد ومراحل تطور تذويل التعليم الجامعي؟ }
$$

(Y)مــا أبـرز الأمثلــة والخبـرات والتجـارب الدوليـة في مجـال تـدوبل التعلـيم

$$
\text { العالي؟ }
$$

(r)مـا أهم آليـات تطبيـق تدوبل التعليم العـالي ومضـامينها بالنسـبة للتعليم

$$
\text { أهمية البحث: }
$$

مـن الناحيـة العمليـة فـان هذا البحث بسـاعد في تتميـة قدرة الجامعـات المصرية على الاستجابة لتحديات ومنطلبات العولمة والاستفادة من مميزاتها في تطـوير منظومـة التعليم الجـامعي المصـرية، كمـا إن هـذا البحـث يثـد أنظـار القيـادات الجامعيـة والمسئولين عـن التعليم العـالي بمصـر إلـى أهميـة تطبيـق استراتيجيات تدوبل التعليم العالي والاستفادة منها، ويقدم لهم دليل في أهم مداخل تذويل التعليم العالي وبما بساعدهم على تبني منثل هذه ممارسات وتطبيقها بشكل فعلي، كمـا يمكـن الاسـتفادة مـن هـذه الدراسـة كأسـاس إعـداد مجموعـة مـن المواصفات والمعايير المصرية التي يتم تبنيها لتدويل التعليم العالي في مصر والحكم على واقع هذا التطبيق. ومن الناحية النظرية فإن هذا البحث يعد إسهام في التقديم لمجال تدويل التعليم العالي بما يساعد الباحثين على توفير خلفية نظربة مكتوبة باللغة العربية حول هذا الموضوع الهام والذي يفتقر الى وجود بحوث وكتابات عربية رصينة حتى يومنا هذا. ومن ناحية أخرى فإن هذا البحث بعد بداية لسلسـة منن بحوث تتناول تدوبل التعليم ورصد واقعه، والكثف عن متطلباته وتقديم تصورات ورؤى مقترحة لتطبيقه. ويساعد هذا البحث في تقديم أساس إجراء سلسلة من البحوث التي تتتاول رصد واقع تدويل التعليم العالي استتاداً إلى قائمـة الممارسات المقدمـة لاى البحث. 
يلتزم هذا البحث بمجموعة من المحددات الرئيسية وهي:

• تتاول ندويل التعليم العالي بشكلٍ نظري مستتد إلى تحليل الأدبيات وثثقة الصلة بهذا الموضوع دون التطرق إلى التطبيق الميداني لأداوت جمع البيانات.

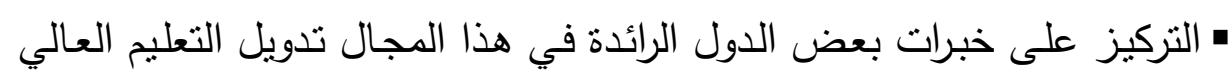
مثل أمريكا، والصين، وكندا، وغيرها من الدول.

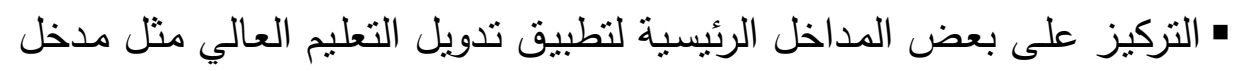
النشاط، والمخرجات، والعمليات، والتدويل الداخلي وغيرها من المداخل.

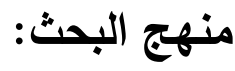

لتحقيق الأهداف الرئيسية للبحث الحالي فإن المنهج الوصفي التحليلي

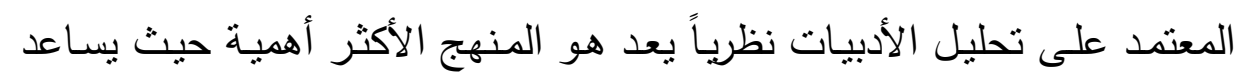

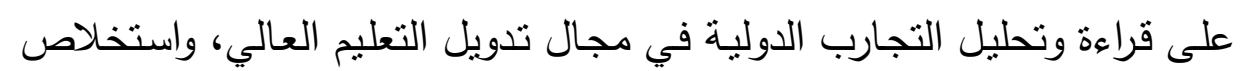

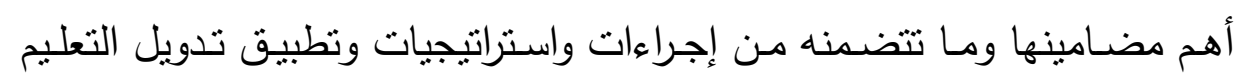

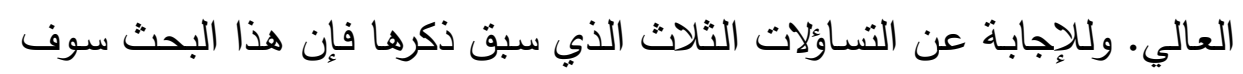
يتتاول بالتحليل والدراسة ثلاث مباحث رئيسية يتتاول أولها تحاليل مفهوم وطبيعة

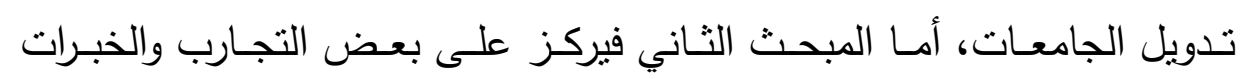

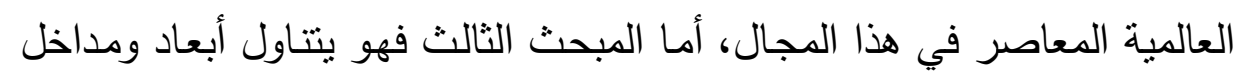
وتطبيق تدويل التعليم العالي، ومراحله، ومنطلباته، وسبل تقييم مستويات تطبيقه. الاراسات السابقة:

بشكل عام، نوجد قلة من الدراسـات العربية التي ركزت على الخبرات العالمية المعاصرة في مجال تدويل التعليم. وفيما يلي نستعرض لعدد من هذه الدراسات.

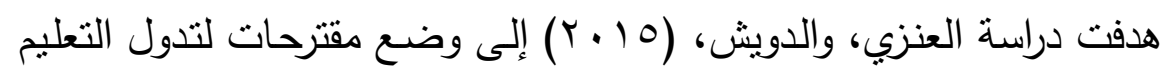

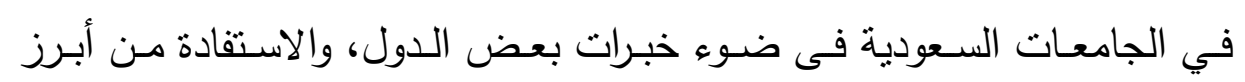

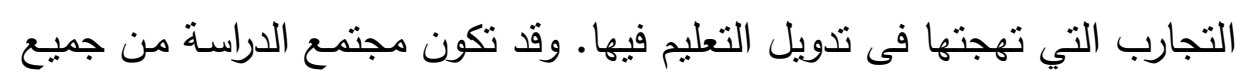


أعضــاء هيئـة التـدريس فـى الجامعـات السـعودية علـى اخـتلاف جنسـهم وتخصصاتهم، واعتمدت الدراسة على المنهج الوصفي المسحي، تم اختيار العينة بالطريقة العشوائية وبلغ عددها (ع Y Y) عضو هيئة تدريس، واستخدمت الاستبانه

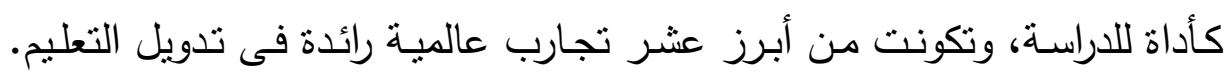

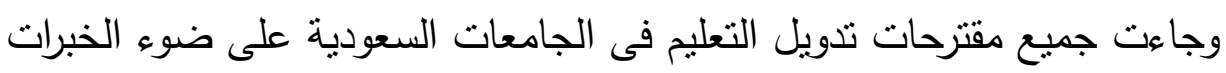

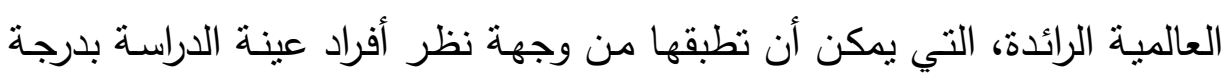

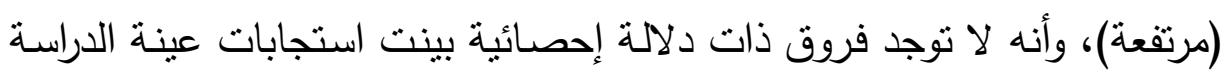

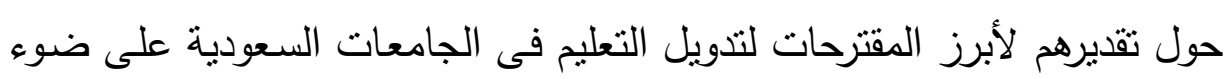
الخبرات العالمية الرائدة يمكن أن تعزى لمتغيري الدراسة (الجنس، والتخصص).

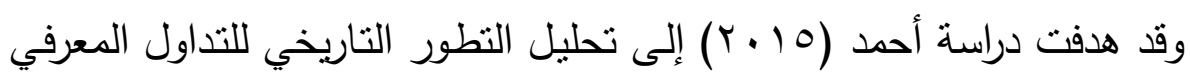

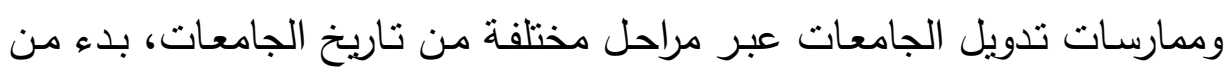

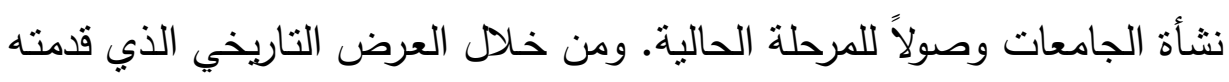
الدراسة اتضح أن تدويل الجامعات كان حاضراً كفكر وممارسة أكاديمية منذ نشأة

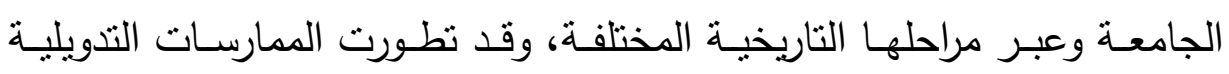
بالجامعات بشكل موازي للتطور الذي شهدنه الجامعة فى تتظيمها ووظائفها. كما ولها

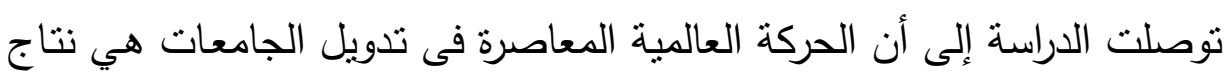

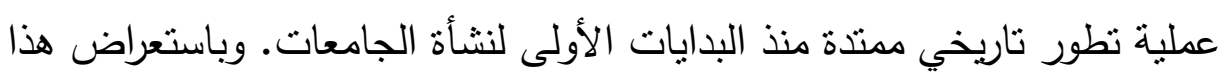
التطور توصلت الدراسة أيضاً إلى أنه خلال العقدين الأخيرين حدث تحولاًا جذرياً

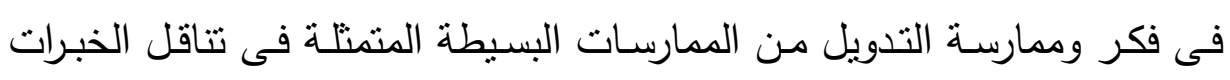
والحراك الأكاديمي للطلاب والأساتذة والتي كانت سائدة طوال الفترات التاريخية

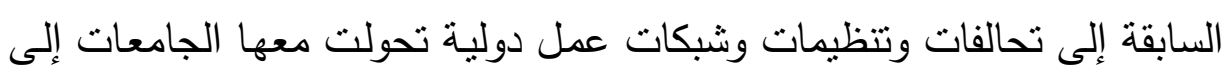

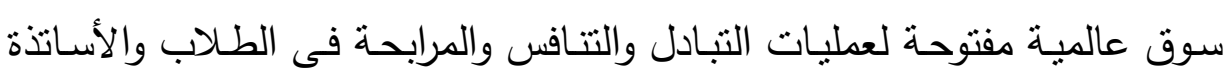

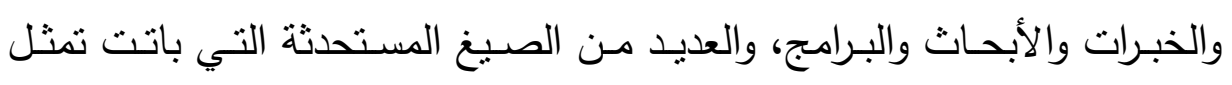
أساس حركة التدويل المعاصر . 
وهدفت الدراسـة التي أجراهـا محمد (ع ا • ب) إلى التعرف على واقع القدرة التنافسية بالجامعات المصرية، ودور تدويل التعليم في زيادتها والارتقاء بها وذلك اهلك من وجهة نظر أعضاء هيئة التدريس في التعليم العالي بجمهورية مصر العربية.

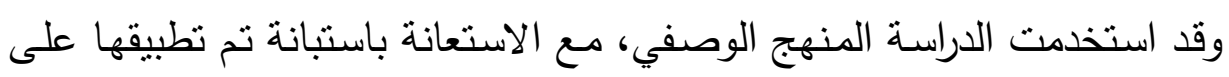

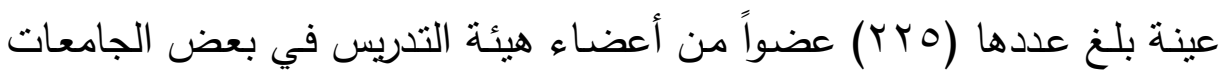

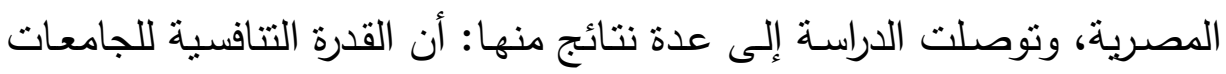

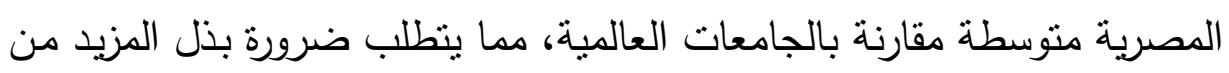

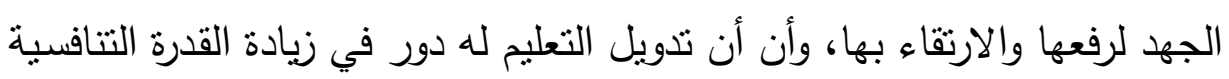

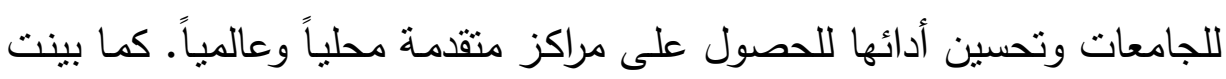

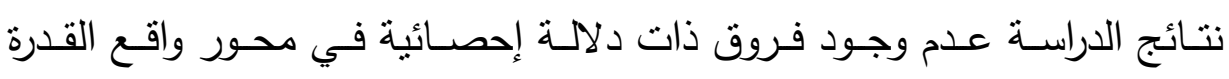
التنافسية للجامعات بين الكليات العملية والكليات النظريـة، ولكن وجدت فروق دالة إحصائيا لصالح الكليات النظرية في محور مساهمة تدويل التعليم في زيادة القدرة التتافسية للجامعات، ومنطلبات تدويل التعليم. وكذلك وجدت فروق دالة إحصائيا بين مجموعات الدراسة لصالح الأساتذة المساعدين في محور واقع القدرة

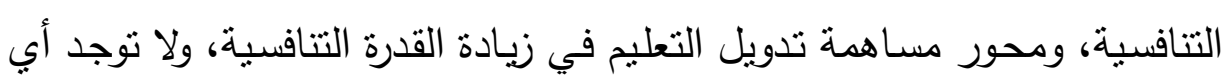
فروق دالة إحصائيا في محور متطلبات تدويل التعليم.

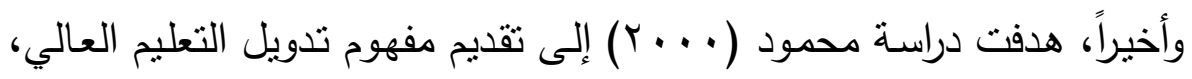

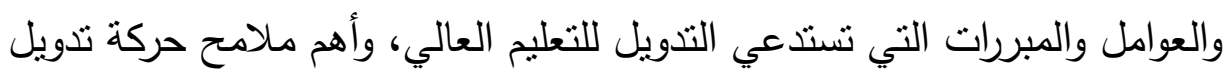

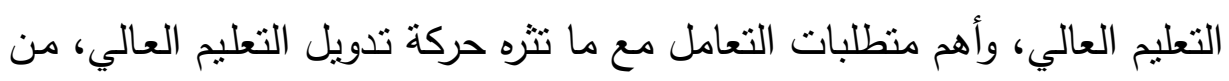

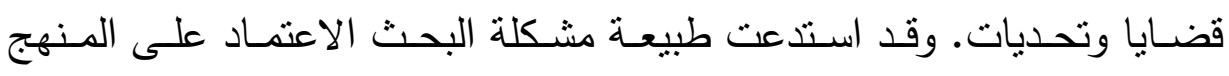

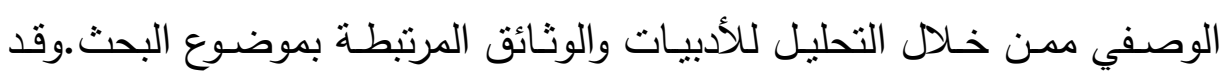

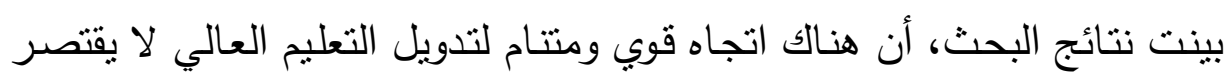

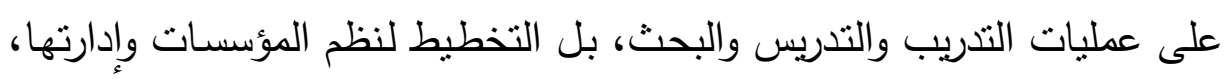

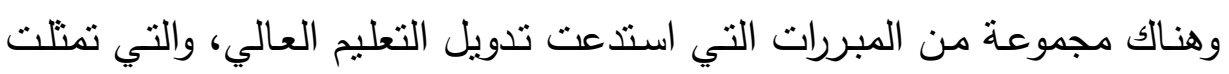


بصـورة أساسـية فـى العولمــة بأبعادهـا الاقتصـادية والسياسية والثقافيـة، وتطـور

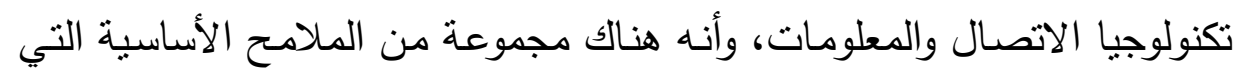

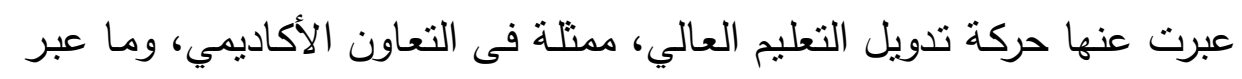

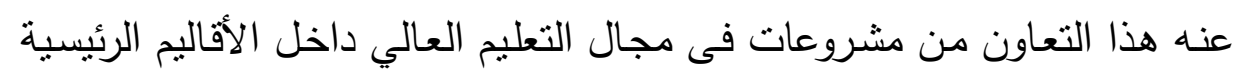

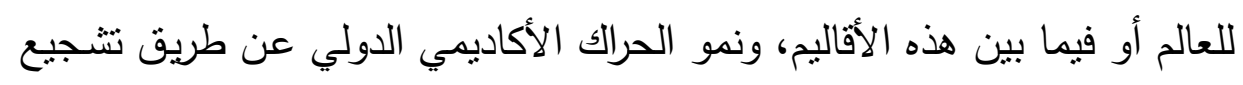

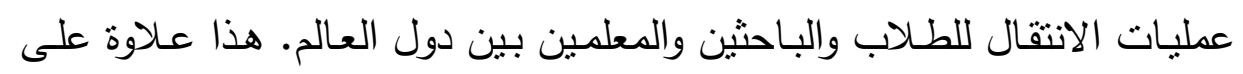

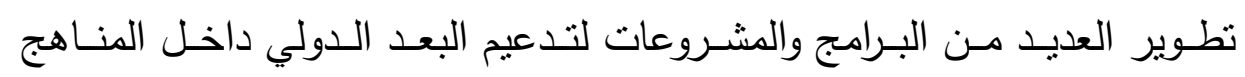

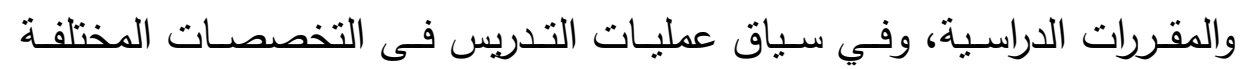
وبخاصة التي تتعلق بعولمة السوق كالتخصصات التجارية والزراعية.

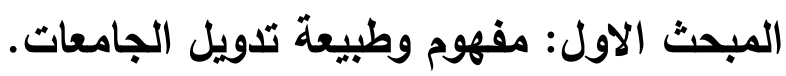

\section{1- 1 - 1 مفهوم تدويل التعليم}

يعني بالتعليم العالي هنا "أثكال الدراسة التي تلي المراحل المدرسية ونوجد فى لئ

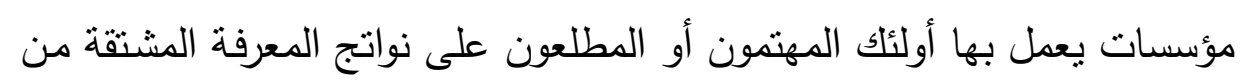

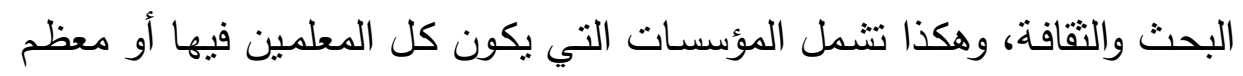

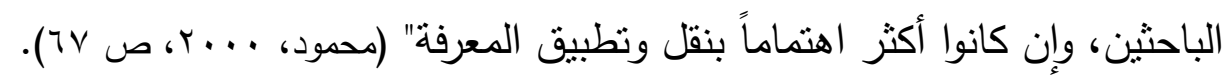

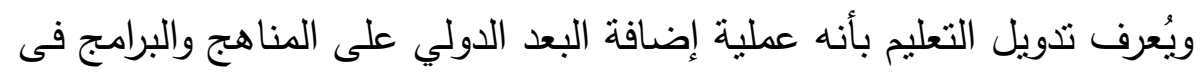

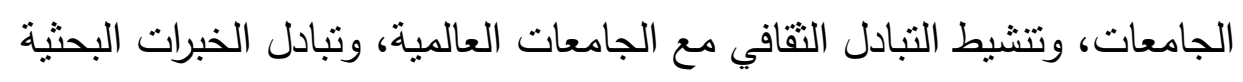

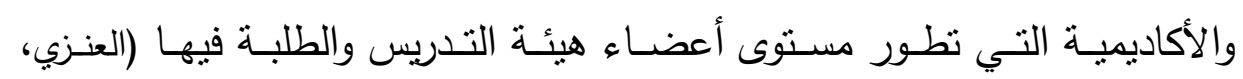

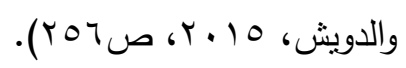

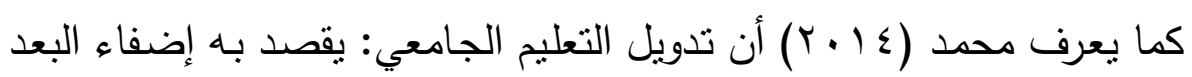

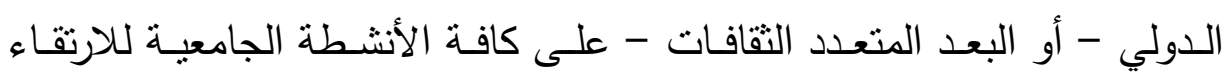

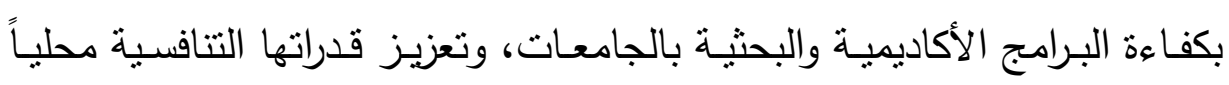
وإقليميا وعالمياً. 


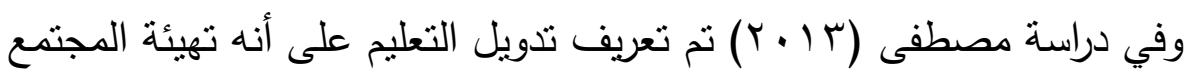

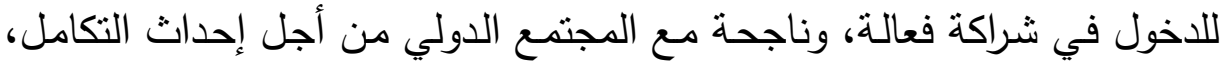
والنتافق، والتتمية بين المجتمعات، والثعوب.

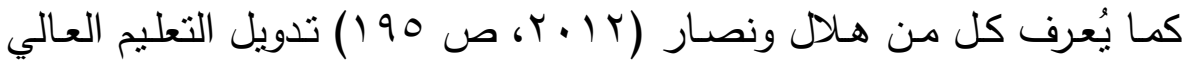
بأنه: " إحداث نوع من الحراك الدولي المنبادل والمتوازن بين مؤسسات التعليم

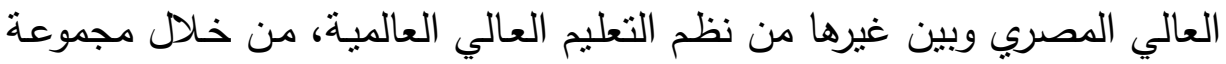

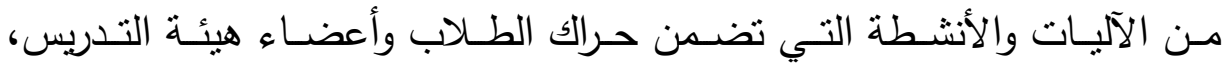
والبرامج التعليمية، والمنـاهج والمقررات الدراسية، والبحث العلمي، وبرامج خدمة

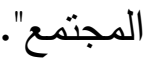

وهكذا فإن التدويل لا يقتصر فقط على تقديم مناهج دولية فى مؤسسات مـا وراء البحار وما يوجد بها من طلاب أو معلمين دوليين، بل بشمل كذلك إدخال

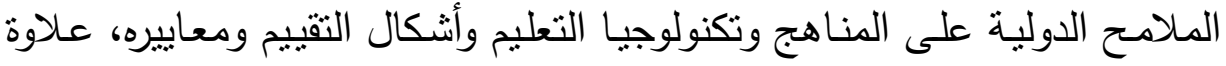
على تيسيرات الحراك الأكاديمي الدولي لكل من الطلاب والمعلمين والباحثين،

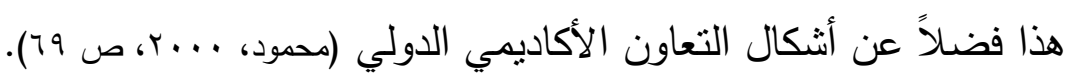
ا ب- الفرق بين مصطلحي تدويل وعولمة الجامعات:

Stromquist \& Monkman,) لمفهومي عولمة وتدويل الجامعات معاني مختلفة

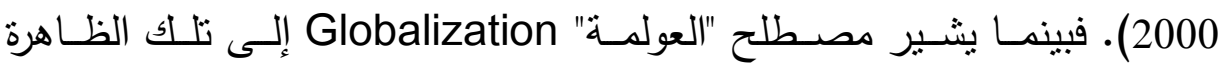
العالميـة التي لا يمكن التحكم فيها لتداخل الحدود والأفكار بين الدول، يثير

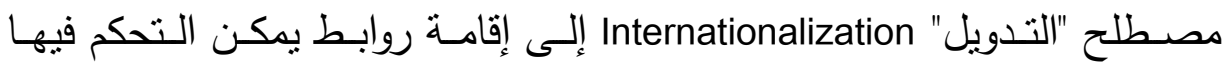
وإدارتها بين المؤسسات أو البلدان، أو الأفراد المنتمين إلى عدة دول مختلفة من العالم (Horn et al., 2007). وتمنل العولمة- في جوهرها - ظاهرة تتميز بتكامل الاقتصاديات، والمجتمعات، والثقافات الإقليمية عبر إقامة شبكة كونية للاتصـال والتجارة تربط بين كافة دول

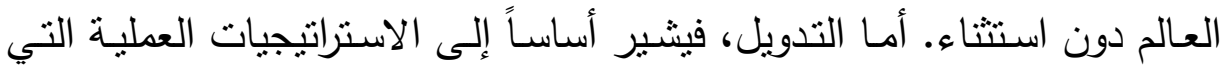


تطبقهـا المؤسسـات، أو البلـدان، أو الأفراد بهـدف محاولـة التكيف مـع ظـاهرة العولمة ومواجهتها (Sadlak, 1998).

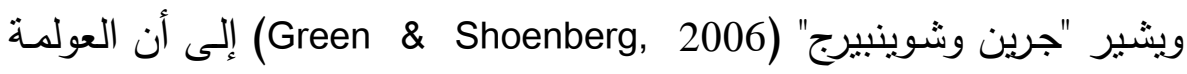

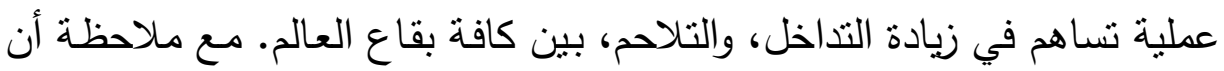
هناك العديد من العوامل المرتبطة بالعولمـة التي ساهمت في إحداث جذري في

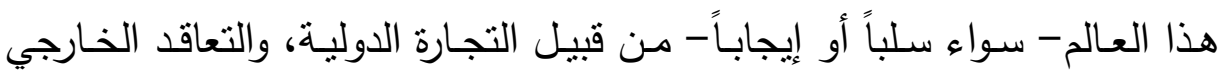

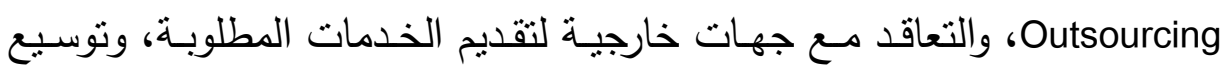
نطاق سلاسل العرض والطلب، وزيادة بروز تأثير القوى السياسية عالمياً. ولكن

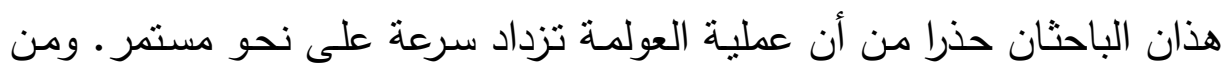

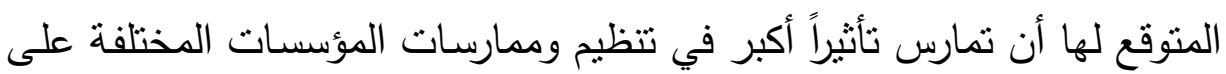
المستوى العالمي مستقبلاً.

فالعولمـة هي السياق الأساسي الذي يمكننا من تفسير التوجهات الاقتصسادية

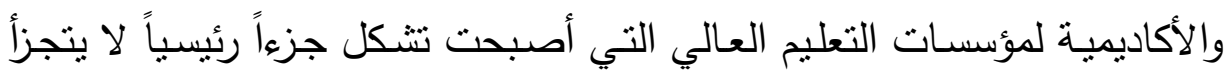
من واقع القرن الحادي والعشرين (Altbach \& Knight, 2007). وقد لوحظ مؤخراً زيـادة معـدلات اسـتخدام مصـطلح التـدويل في وصـف عمليـة زيـادة مشــاركة Dellow \& Romano, ) الجامعات ومؤسسات التعليم العالي في السوق الدولية

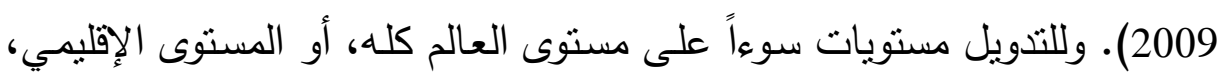

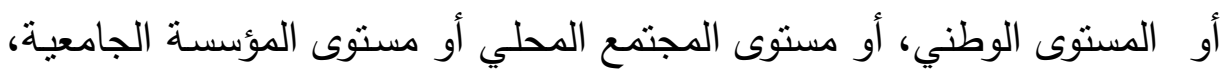
أو حتى على المستوى الفردي (Mestenhauser, 2000, 2002). 1-ب التطور التاريخي التدويل الجامعات:

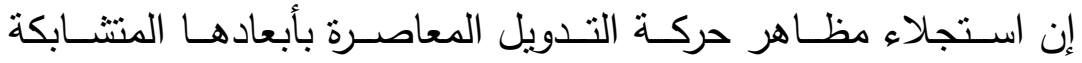
واتجاهاتها المتتوعة يستلزم بداية التعرف على مراحلها التاريخية المتخلفة، والأبعاد

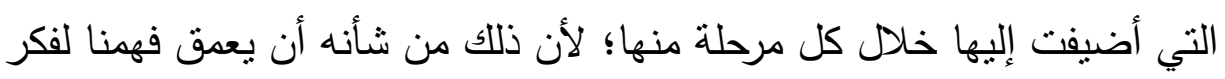


وفلسفة التدويل الجامعـات، ويزيــ مـن قدراتتا على التتبؤ بتطوراتها المستقبلية

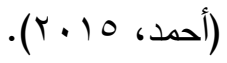

يؤكد "ماكمورتري" (McMurtrie, 2007) على أن مفهوم التدويل المستخدم في التعليم العالي ليس بالمفهوم الجديد، إنما قد شهد تطورات كبرى على مر السنين.

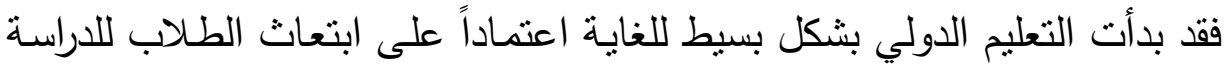

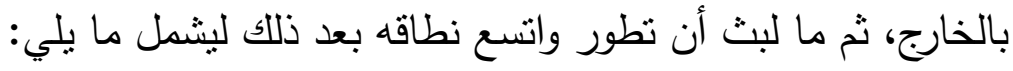
• تقديم التعليم الجامعي كخدمة عامة. • تطور أنشطة البحث العلمي.

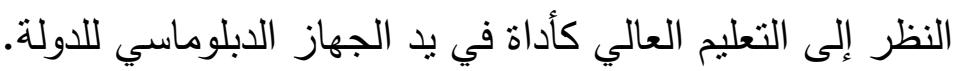

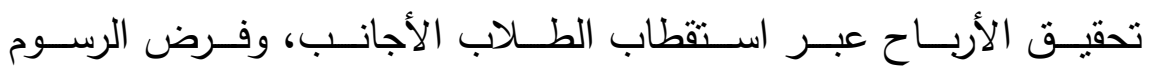
والمصروفات الدراسية. ويشير "دي ويت" (De Wit, 2002) إلى أنه في الفترة الزمنية السابقة القرن العشرين، "كان البعد الدولي للتعليم العالي عملية أقرب مـا تكون إلى الصدفة والعشوائية منها إلى العمل المنهجي المنظم". ويحدد "فيستال" (Vestal, 1994) ثلاثة مراحل تاريخية رئيسية لتطور تدويل الجامعات، وهي: التهي: أ- حقبة ما بعد انتهاء الحرب العالمية الثانية: The Post-World War II Era

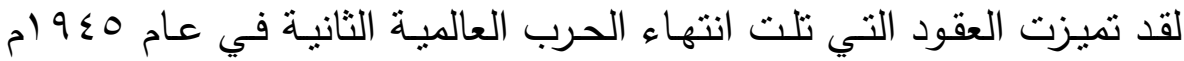

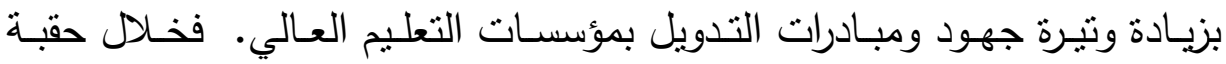
الحرب الباردة، ألزمت الحكومة الفيدرالية والمؤسسات الكبرى بالمجتمع الأمريكي نفسها بتخصيص قدر كبير من الموارد للارتقاء بمجالات دراسة العلاقات الدولية،

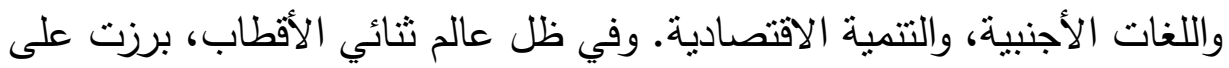

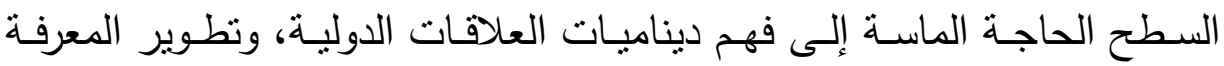
بالمجتمعات، والنظم السياسية والاقتصادية للمنافسين، والحلفاء الدوليين، إضـافة 
إلى غيرهم من الأمم الأخرى التي تتحر من نير الاستعمار في ظل تزايد الاهتمام

بمعرفة ولائاتها في إطار منافسات الحرب الباردة على مناطق النفوذ لإن عالمياً".

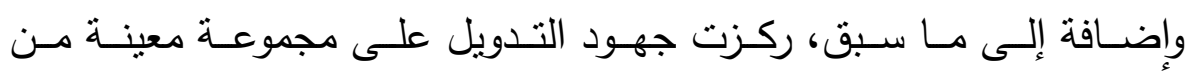
المشروعات الأكاديمية التي تسارعت وتيرتها خلال عقدي الستنيات والسبعينيات

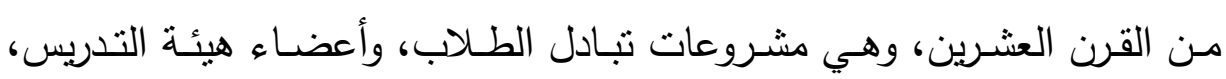

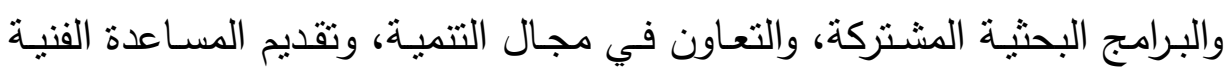
(Barker, 2000)

وفي ظل ضـخ استتمارات مالية كبرى بغرض التتمية في قارات آسيا، وأمريكا

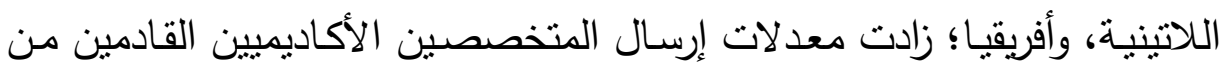

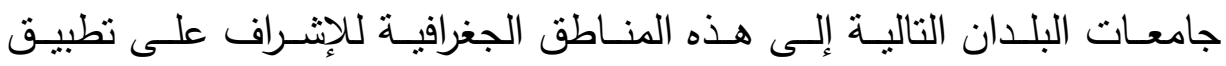
مشـروعات التتميـة، وإجراء عمليـات التدريب والتعليم، وهي جامعـات كل من هن:

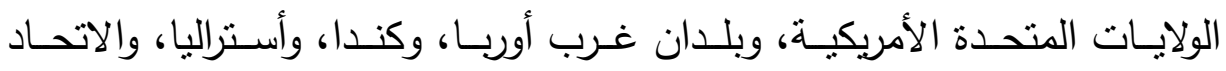
السوفيتي. وسيطرت على هذه الحقبة التاريخية العلاقات بين الثمال والجنوب،

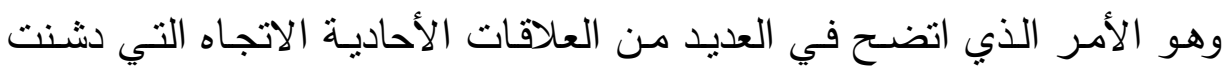
خلال هذه الحقبة. فعلى سبيل المثال، برز خلال هذا العصر اتجاه لزيادة تدفق الطلاب من الجنوب إلى الثمال، وبالمقابل، سجلت معدلات تدفق أعضاء لهاء هيئة التدريس من الثمال إلى الجنوب نمواً كبيراً (De Wit, 2002). ب- تدويل التعليم العالي في عصر العولمة:

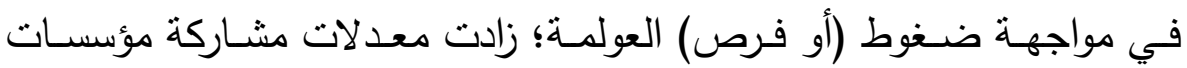
التعليم العالي في سوق المعرفة/المعلومات الدولية في الوقت نفسـه الذي تحاول

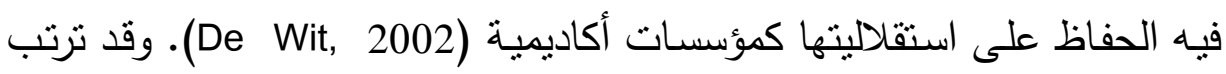
على هذه التوجهات الجديدة العديد من المخرجات العملية الهامة بالنسبة لمنظومة

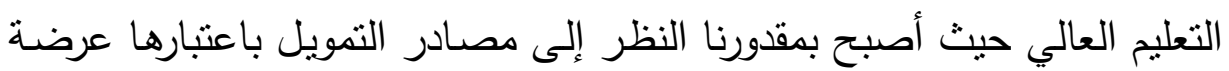

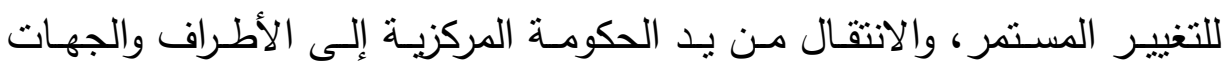


الأخـرى مـن أصـحاب المصـالح- بمـا فـي ذلـك: مؤسسـات القطـاع الخـاص،

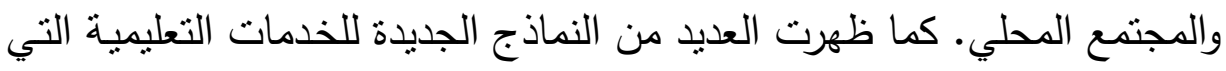
ترتب عليها مضامين علمية كبرى ساهمت في تطور التعليم الدولي نتيجة لنزايد معدلات الوسائل التكنولوجية الجديدة في تقديم التعليم عبر الحدود القومية للدول.

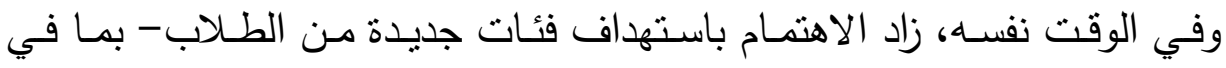
ذلكالمتعلمون الكبار السن، والمهنيون العاملون في الوظائف المختلفة، وغير ذلك من الفئات الأخرى للطلاب غير التقليديين (Deem, 2001). وبينما تبنت جهود تدويل الجامعات - بشكل عام - خطاب التعاون والثـراكة والاستفادة من خبرات وتجارب الماضي، فإن لغة التدويل شهدت تغيرات كبرى

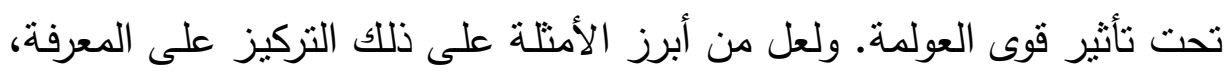

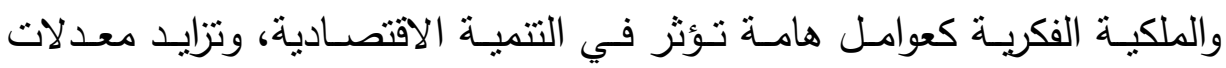
المنافسة عالمياً، وضبط ، والتسويق التجاري. ووفقاً لـ "توربين وزملاؤه" ( Turpin (et al., 2002 بالاستفادة من تطبيق ممارسات مجال إدارة الأعمال في المؤسسات الأكاديمية،

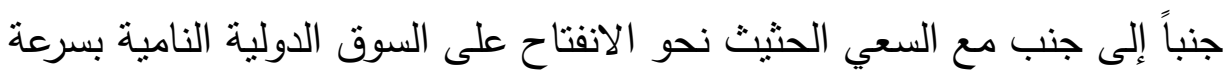

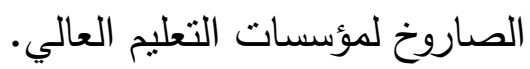
وأضاف "كارنوي ورهوتين" (Carnoy \& Rhoten, 2002) إلى ما سبق عدد من

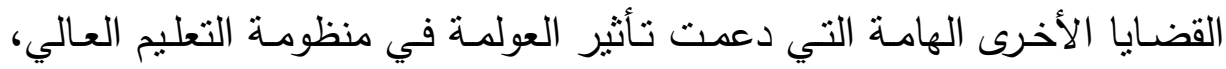
وهي: اللامركزية، والخصخصـة، والمحاسبية التعليمية. وقد ارتبط اتسـاع نطاق تدويل مؤسسات التعليم العالي بتدني مستويات رقابـة وتحكم الدولـة في نظمها للتعليم العالي، جنباً إلى جنب مع تزايد معدلات تقديم البرامج والخدمات التعليمية العابرة للحدود القومية في ظل تزايد وتيرة تطبيق أطر عمل دولية حاكمة (مثل:

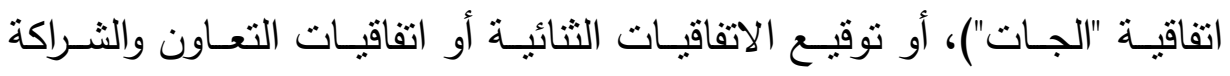

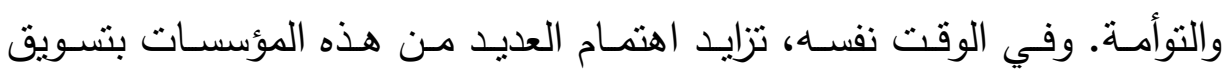


منتجاتها (التعليمية، والمعرفية) على المستوى العالمي. وفي الوقت الذي لم تغب

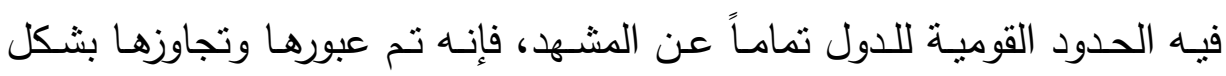
متزايد بغرض عرض أو طلب تقديم برامج التعليم العالي (Marquardt, 1999).

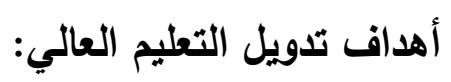

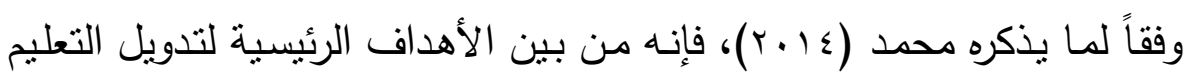
العالي ما يلي:

(1)تقليص الفجوة المعرفية الموجودة بين الجامعات في الدول المتقدمة والدول النامية، والحد من هجرة الكفاءات العلمية عن طريق المساعدة على إنثاء أقطاب امتياز في الدول المختلفة. (Y)بناء القدرات التنافسية لمؤسسات التعليم العالي والجامعي، وتحقيق التقدم في مختلف المجالات العلمية والتكنولوجية. (r)زيادة الوعي الدولي بين الطلاب والباحثين وتتمية التفكير والبحث في القضايا

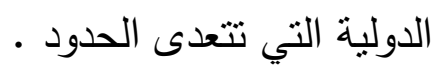

(ع)الربط بين مؤسسات التعليم العالي في الدول المتقدمة والدول النامية، وذلك

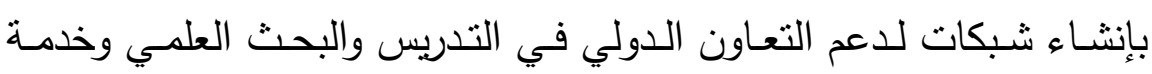
المجتمع الدولي.

(0)تعزيز التعاون العلمي والفكري عن طريت التوأمسة والتعاون الأكاديمي بين مؤسسات التعليم العالي والجامعي في شتى أنحاء العالم.

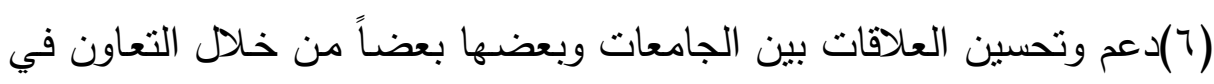
الأبحاث المشتركة وتكوين التحالفات الاستراتيجية وتبادل الطلاب والباحثين بما يحقق التقدم والمنافع المشتركة لهذه الجامعات. 
المبحث الثاني: أمثلـة للخبرات العالميـة والتجـارب الدوليـة الرائدة في مجـال

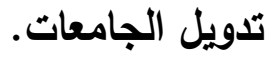

فيما يلي سيتم استعراض أبرز الخبرات والتجـارب العالميـة الرائدة في مجال تدويل الجامعـات مرنبـة في عدة دول وهي: بلـدان أمريكا الثـمالية (الولايـات

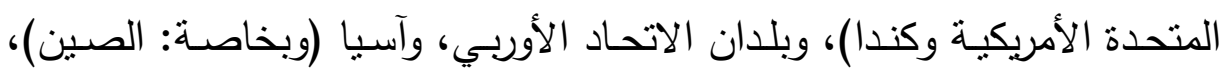
وأستراليا، وأمريكا اللاتينية، وأفريقيا.

ץ-1 - تجارب الولايات المتحدة الأمريكية وكندا في تدويل التعليم العالي والي

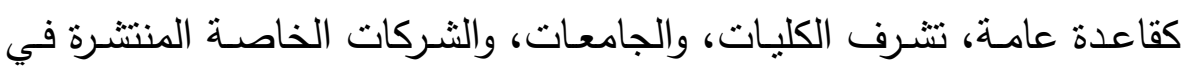
كافة أرجاء الولايات المتحدة الأمريكية على تطبيق العديد من المبادرات وعلاقات الثراكة الهادفة إلى تدويل مقراتها وبرامجها الجامعية بما يتجاوز الحدود القومية

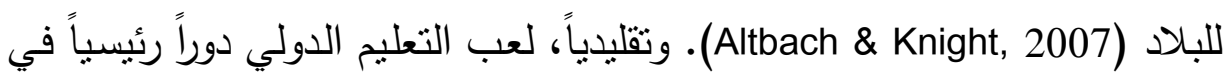
تطور التاريخ الأمريكي، والثقافة، والحضارة الأمريكية.

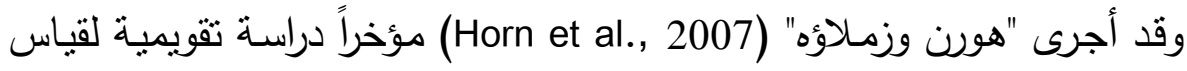

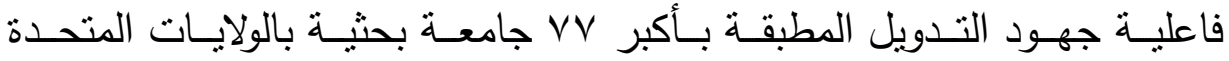

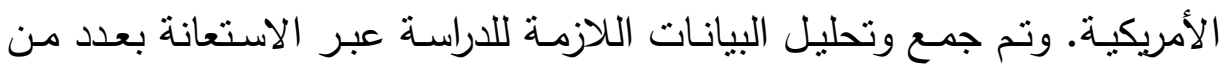

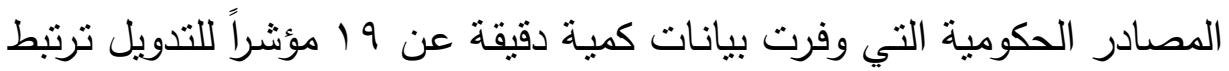

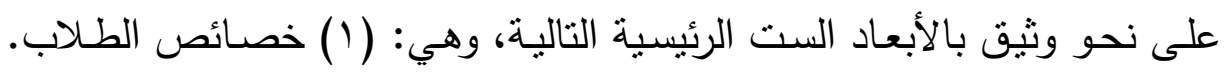

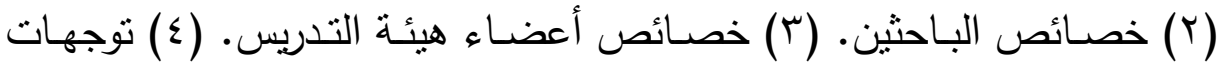

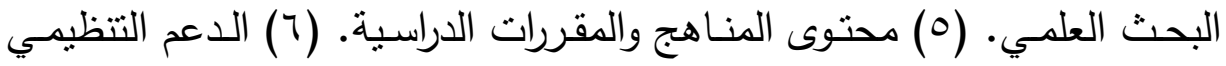
للتدويل على المستوى المؤسسي. واستعان الباحثون بما تم جمعه من أرقام في تصنيف درجة التزام الجامعات المشـاركة في الدراسـة بالتدويل. وكثنفت النتائج النهائية للاراسة عن أن V من أكبر ل 1 جامعة بحثية بالولايات المتحدة الأمريكية

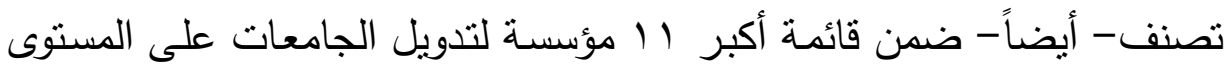
الوطني الأمريكي - بما في ذللك: ( () جامعة كولومبيا. (Y) جامعة كاليفورنيا- 
بيركلي. (r) جامعة هارفارد. (ع) جامعة بال. ومن هنا؛ أثنارت هذه النتائج-

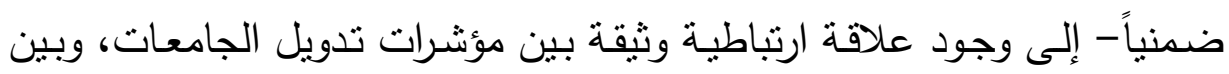
مؤشرات فاعلية أداء أنشطة البحث العلمي.

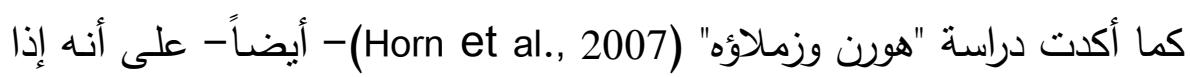
نظرنا إلى التدويل كواحد من أبرز أولويات الجامعات البحثية بالولايات المتحدة

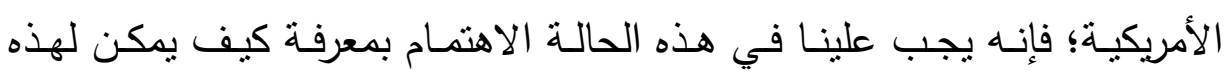

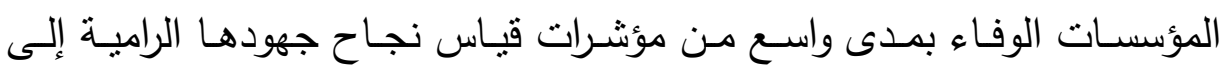

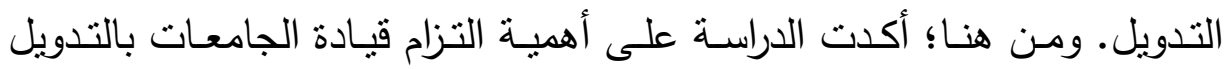
موضحة أن هناك بعد مؤسسات التعليم العالي في الولايـات المتحدة الأمريكيـة

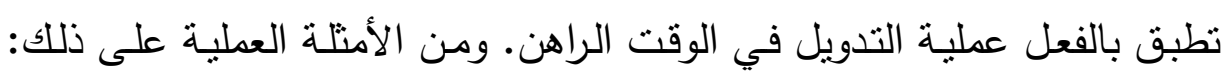

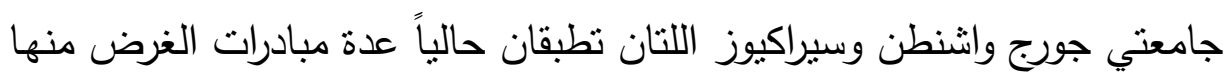
هو : إنشاء فروع لهما بكوريا الجنوبية.

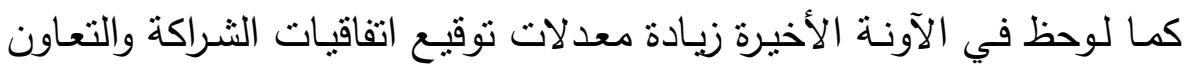

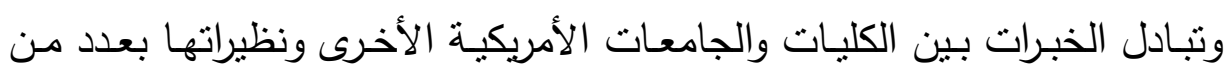

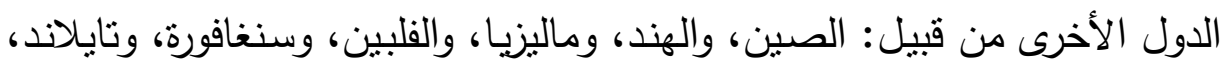

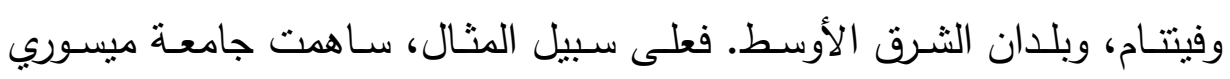

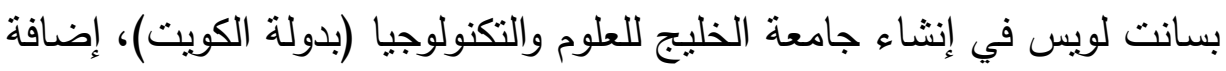

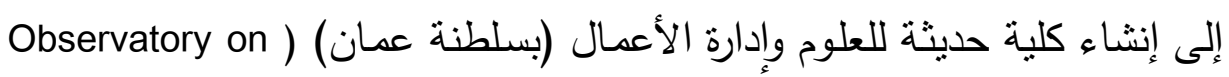
.(Borderless Higher Education, 2010 وعلى الجانب الآخر، نجد أن كندا لا تزال تتخلف كثيراً عن ملاحقة غيرها من . البلدان الأخرى الناطقة بالإنجليزيـة في مجال تدويل الجامعات، مثل : الولايـات

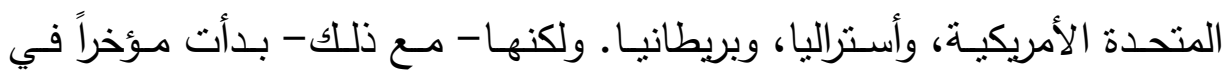

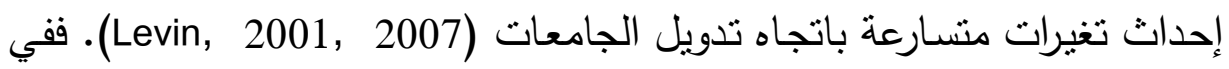

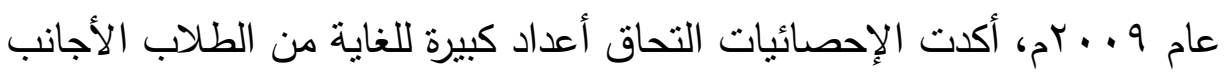


بالجامعات الكندية- بما في ذلك: طلاب قادمين من الولايات المتحدة الأمريكية .(McCarthy, 2007) فعلى سبيل المثال، مثل "المعهد الكندي للإدارة الدولية" (CIMI, 2010) عشرة من الكليات والجامعات الكندية المختلفة، في توقيع اتفاقية مع المجلس الصيني

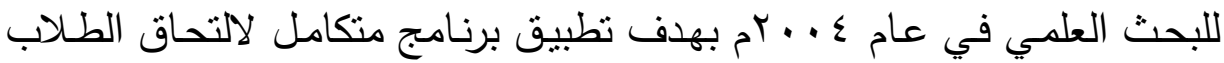
الصينيين الراغبين بالدراسة للحصول على درجات أكاديمية متتوعة من الجامعات الكندية. وينص هذا البرنامج على بقاء الطلاب في الصين خلال السنوات الثلاث الأولى من مدة تطبيق هذا البرنامج الذي يمتد لخمسة أعوام كاملة يدرسون فيهاء أساسيات العلوم، وآليات التوافق والحوار الثقافي، إضافة إلى التدريب على لـى إتقان اللغة الإنجليزية. وبعد ذلك، يمكن لهؤلاء الطلاب الانتقال إلى كندا خـلال العامين الجامعيين المتبقيين إذا مـا رغبوا في إكمـال متطلبـات الحصـول على الدرجات الجامعيـة المطلوبة. ومن بين مبادرات التدويل الأخرى التي تترف عليها مؤسسات كندية

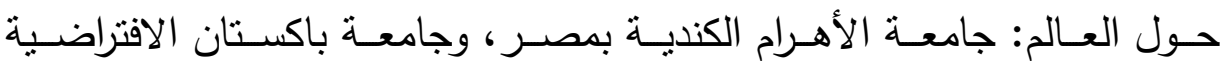
.(Altbach \& Knight, 2007) ץ- 1: تجارب بلان الاتحاد الأوريب في تدويل التعليم العالي: يسعى الاتحاد الأوربي بخطى حثيثة نحو تدويل منظومة التعليم العالي ببلدانه المختلفة كجزء من أهدافه الاستراتيجية لتحقيق التكامل الاقتصادي والسياسي بين لإنيل كافة بلدان القارة الأوربية (Bruch \& Barty, 1998). ولعل من أول البرامج التي طبقت في هذا المجال: مشروع "إيرازموس" ERASMUS للتبادل الطلابي الذي هن الذي ركز على منح الطلاب الأوربيين الفرصة لاكتساب خبرات أكاديمية ذات صبغة إنسات دولية (Altbach \& Knight, 2007). تلى ذلك بروز "عملية بولونيا" Bologna Process التي وسعت من نطاق

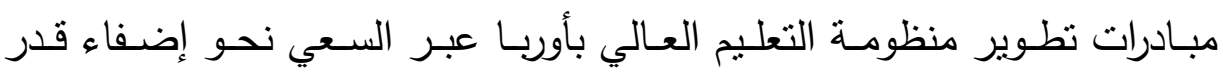


مناسب من الاتساق والتتاغم على النظام الأكاديمي بالدول الأعضاء ككل على

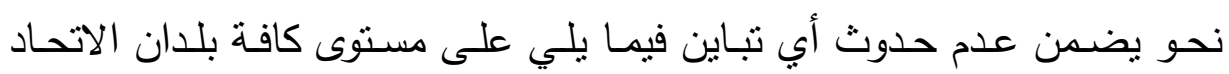

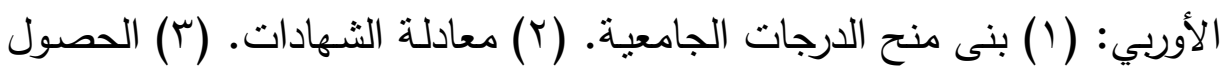
على مؤهلات أكاديمية منساوية في المستوى والفاعلية.

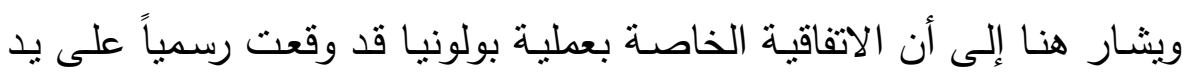

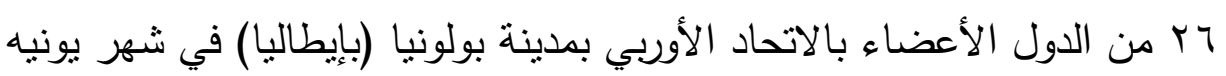

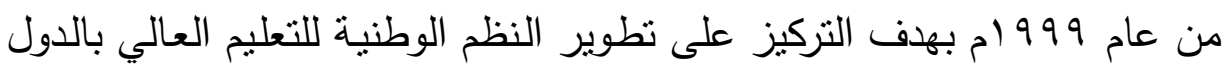

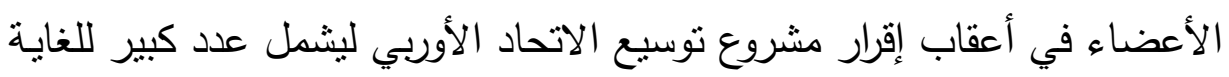

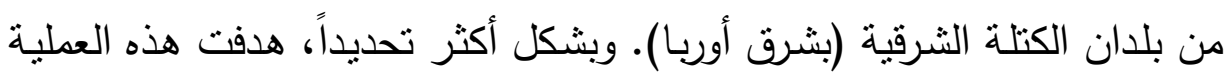

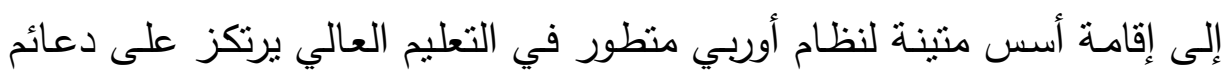

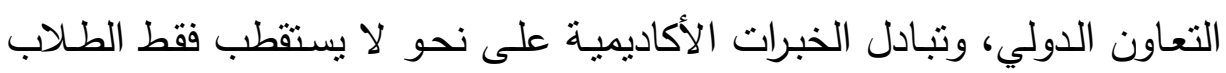

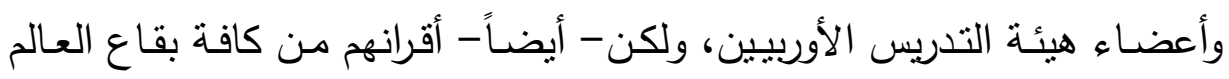
.(Altbach \& Knight, 2007) كما تسعى الاتفاقية- أيضاً - إلى تحقيق الأهداف الثنات الرئيسية وهي: (1) (1) (1)

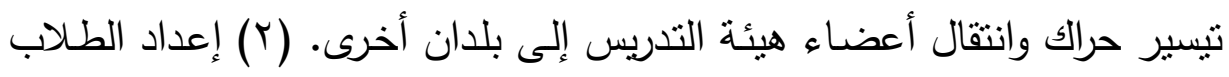

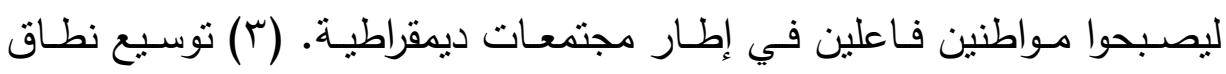
التحاق الطلاب بمؤسسات منميزة عالمياً للتعليم العالي تتميز بالتركيز على القيم دئي الايمقراطية، والحرية الأكاديمية (Bologna Process, 2010). ووفقاً لأحدث الإحصائيات المتاحة لدينا حالياً؛ تطبق عملية بولونيا على 17

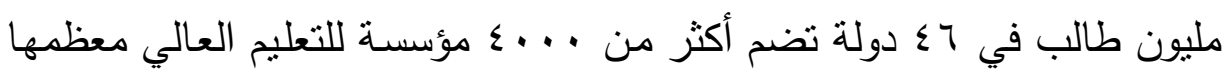

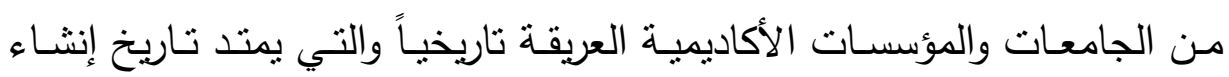

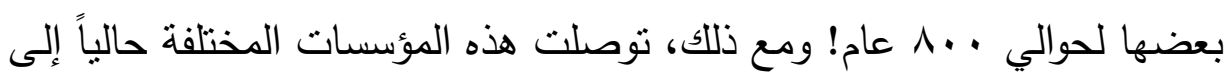
اتفاق على تبني مجموعة موحدة من القواعد والمعايير فيما يتعلق بالجوانب التالية

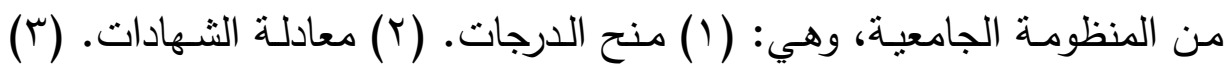


الاعتمــاد الأكـاديمي، وضـمان الجـودة. (ع) نشــر نتـائج ومخرجـات الطـلاب .(Adelman, 2008)

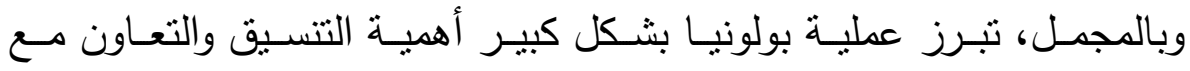

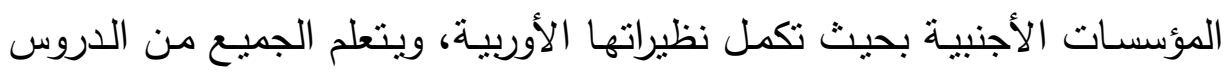
المستفادة. ونتيجة لذلك؛ صيغت معالم سياسات بحثية جديدة تمخضت عن إقامة

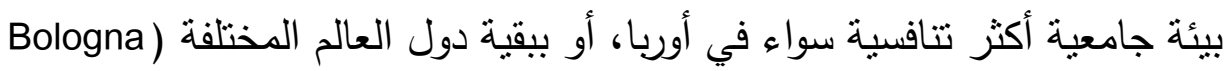
.(Process, 2010 ويقر "ألتباش ونايت" (Altbach \& Knight, 2007) أنه مقارنـة بيقية بلدان شمال أوربا؛ فإن روسيا تمكنت من تطبيق إصلاحات اقتصادية كبرى نرتب عليها

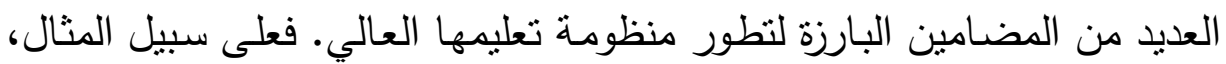

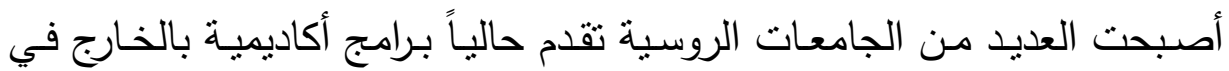

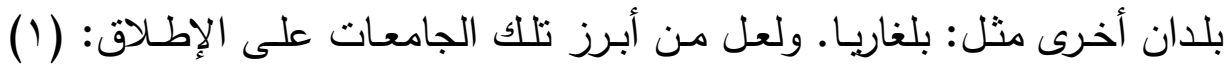

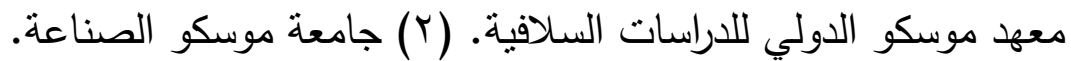

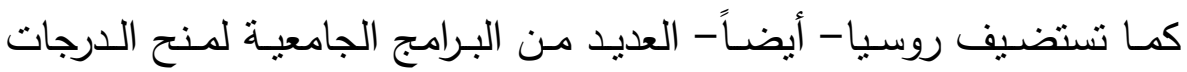
المشتركة، والتوأمسة، وتبادل الخبرات والطلاب مـع عدة بلدان متتوعة من العالم.

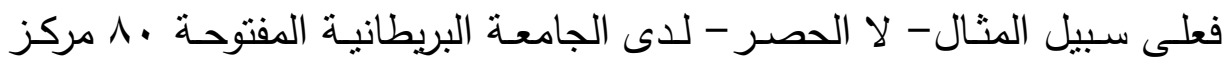

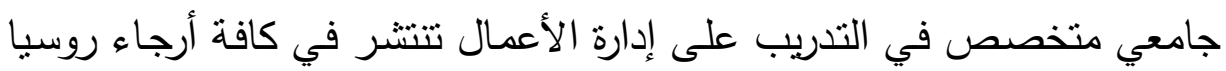
.(Observatory on Borderless Higher Education, 2010)

\section{ץ-r تجرية أستراليا في تدويل التعليم العالي}

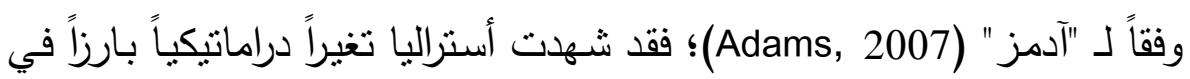
مجال تدويل الجامعات على مدار العشرين عامـاً الماضية في أعقاب تركيز

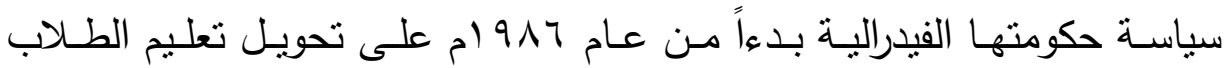
الأجانب من نشـاط مدعم يتم تمويله من أموال دافعي الضرائب؛ ليصبح خـالال

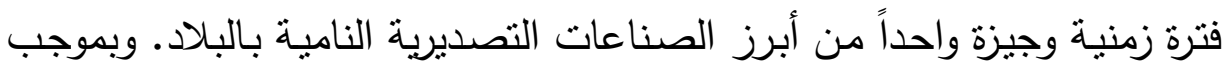


هذه السياسة؛ حظر قانوناً على مؤسسات التعليم العالي تقديم دعم مالي للطلاب الأجانب من أموال المخصصات والاعتمادات الحكومية.

وعلى الرغم من أن الحكومـة هناك منحت الجامعات الحريـة الكاملـة في إدارة ميزانياتها وتقرير حجم المصروفات والرسوم الدراسية المقررة على الطلاب، فإنها

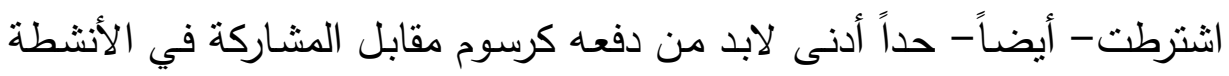

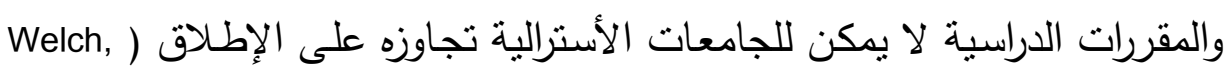

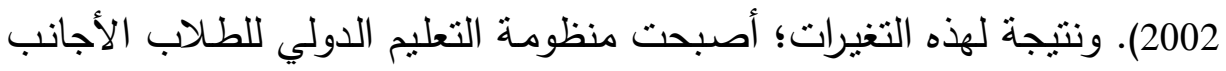

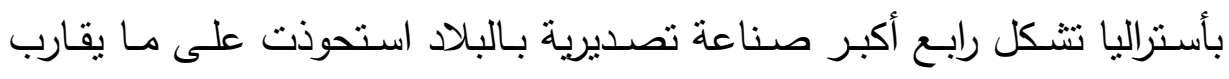

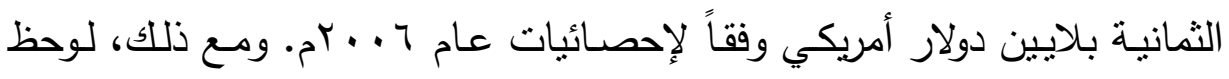

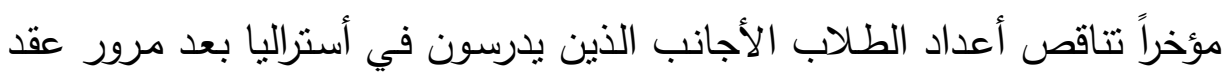
كامل من التوسع والانتشار عالمياً.

\section{ץ- - : تجارب دول أمريكا اللاتينية في تدويل التعليم العالي:}

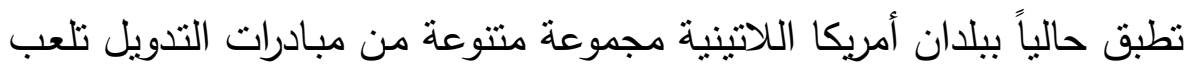

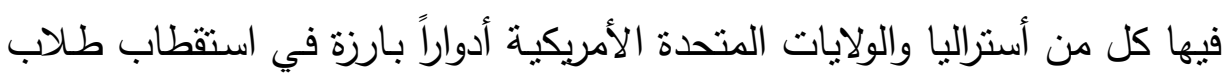

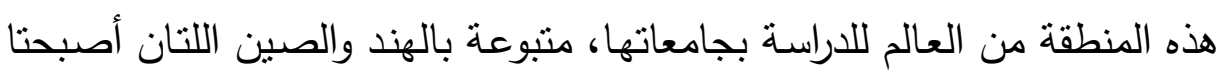
Avila, بشكل متزايد من الدول النشطة في مجال تدويل الجامعات بهذه المنطقة بهنة (2007

Observatory on Borderless Higher ) ومع ذلك، أنثارت دراسة حديثة (Education, 2010 تتكرر من جديد أخطاء الماضي الذي شهذ استغلال الجامعات الأجنبية لمواطنيها

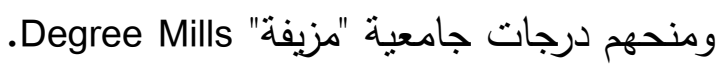
ومن هنا؛ سعت هذه البلدان بكل قوة إلى تعزيز الإتشراف الحكومي على برامج التعليم الدولي لمنع تكرار هذه الأخطاء من جديد. ومن ثم يواجه تدويل الجامعات

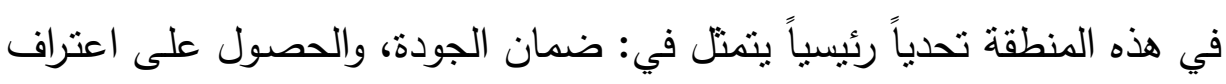


وطني ودولي بالمؤسسـات، والبرامج، والثـهادات، والمؤهلات الجامعيـة الأجنبيـة بسبب الخبرات السلبية لهذه الدول (De Witt, 2005).

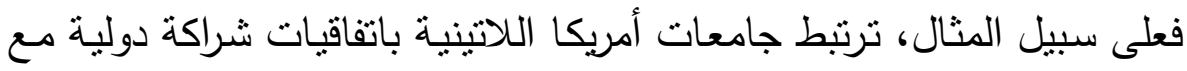

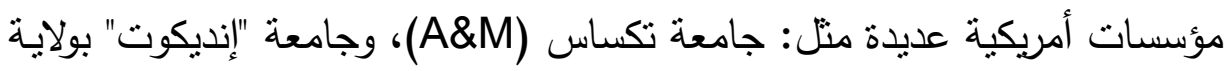
ماساشوستس. ومن الثـائع كذللك عقد اتفاقيات شـراكة مـع الجامعـات الأوربيـة. فعلى سبيل المثال، لدى جامعة بولونيا (بإيطاليا) عدة فروع بالبلدان التالية:

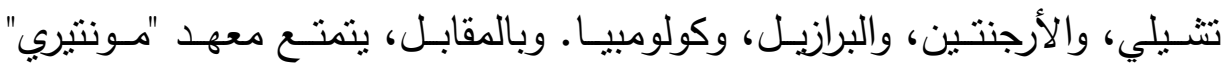

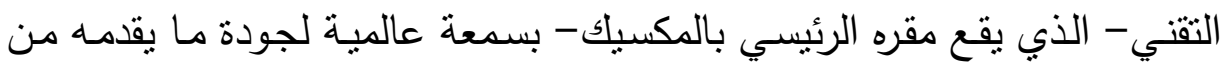
برامج للتعليم عن بعد والتعليم الإكتروني لطلاب العديد من بلدان أمريكا اللاتينية والبحر الكاريبي (Altbach \& Knight, 2007). r -ه تجارب أفريقيا في تدويل التعليم العالي:

تعدل الدول الأفريقية من أدنى أعداد ومستويات مبادرات التدويل المطبقة على لهى المستوى العالمي- مـع وجود بعض الاستثناءات في جنوب أفريقيا ( Altbach \&

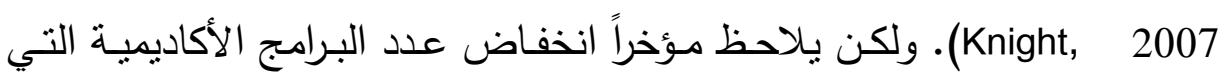

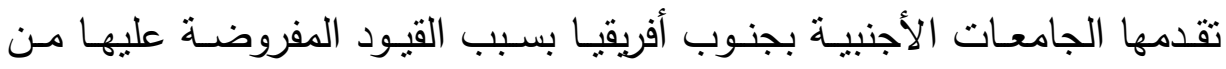
القوانين والتتـريعات الحكوميـة الجديـدة، وتطبيـق عمليـات صـارمة في ضـمان

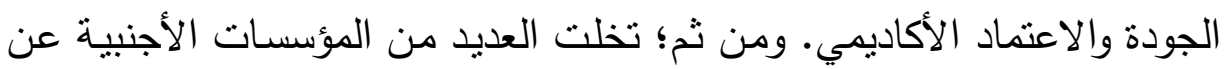
خططها للانتشار في جنوب أفريقيا. ولعل من الأمتلة العملية المحدودة على المؤسسات الجامعية التي لا تزال لها فروع بجنوب أفريقيا كل من: (1) جامعتي بوند، وموناش (الأستراليتين). (r)

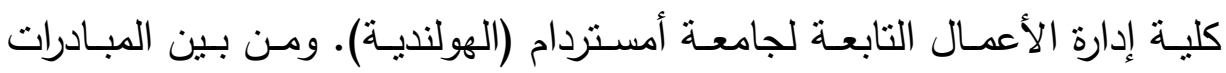
الأخرى المحدودة للتدويل على مستوى القارة الأفريقية خارج نطاق جنوب أفريقيا:

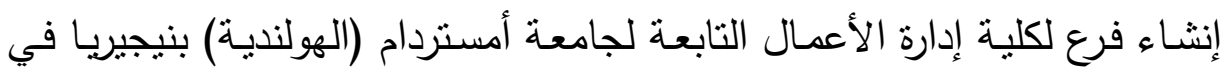

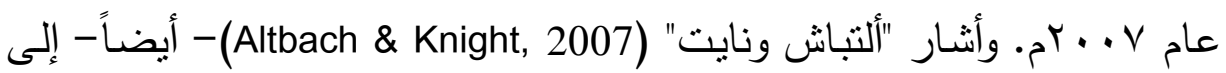


افتتاح جامعة "الأغاخان" (الباكستانية) لفرع لها في كينيا بشرق أفريقيا في عام r . . r لإعداد المتخصصين في العمل بالتمريض.

المبحث الثالث: تطبيق تدويل التعليم العالي r- إخل تطبيق تدويل التعليم العالي:

فيما يلي ينم استعراض أبرز المداخل لتطبيق تدويل التعلم العالي وذلك وفقاً لتصنيفات قدمها العديد من الباحثين في المجال: أولاً: تصنيف "كيانج" لمداخل تطبيق تدويل التعلم العالي: زودنا "كيانج" (Qiang,2003) بنموذج آخر مقترح لتدويل الجامعات يتضمن أربعة مداخل رئيسية هي:

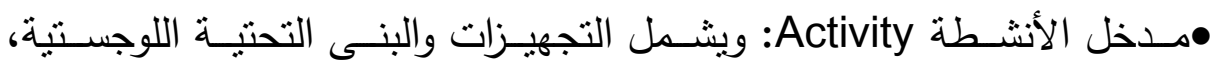
والجوانب الماديـة (الملموسـة) لتـدويل الجامعـات، مثلـ المنـاهج الدراسية،

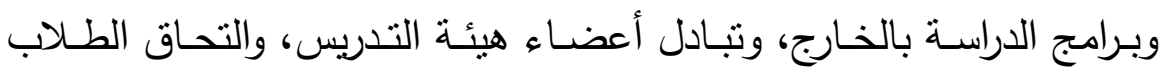

$$
\text { الأجانب. }
$$

•مدخل الكفايات Competency: ويركز على صقل المهارات الفعليـة اللازم توافرها من أجل أداء أنشطة التدويل.

•مدخل التقاليد Ethos: ويرتبط على نحو وثيق بإرساء دعائم ثقافة مؤسسية داخل الحرم الجامعي تتميز بالدعم الفعال لكافة جهود ومبادرات التدويل. •مدخل العمليات Process: ويركز على صياغة السياسـات الجامعية اللازمـة لاعم وتعزيز فاعلية تطبيق مبادرات التدويل. وبالمجمل، يؤكد "كيانج" (Qiang, 2003) على ضرورة إتباع مدخل متكامل

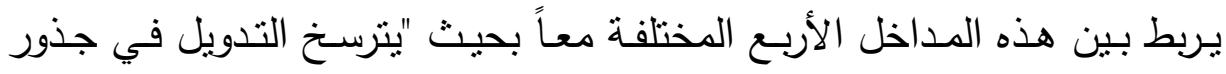
التقافة، والسياسة المطبقة، والتخطيط، والعمليات التنظيمية التي تقوم بها المؤسسة

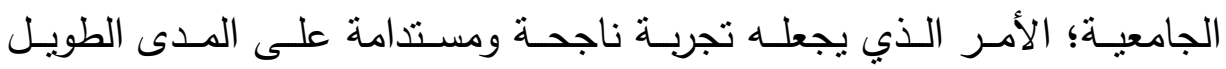

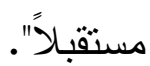




\section{ثانياً: تصنيف "دي ويت" لمداخل تطبيق تدويل التعلم العالي:}

صنفت "دي ويت" (De Wit, 2002) المداخل المؤسسية المستخدمة في تدويل

$$
\text { الجامعات في إطار ستة مداخل رئيسية هي: }
$$

أ- مدخل النشاط Activity Approach:

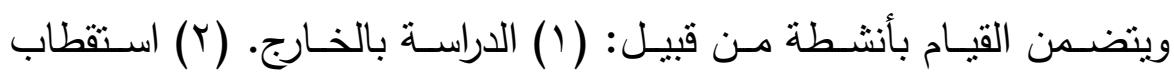

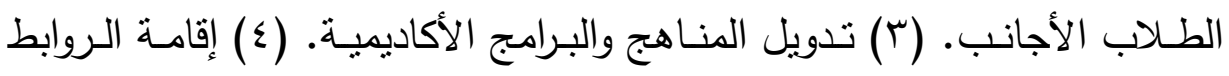

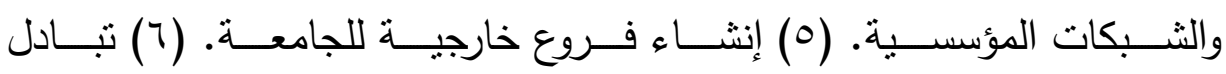

$$
\text { الطلاب/أعضاء هيئة التدريس. }
$$

ب- مدخل المخرجات Outcomes Approach:

ويتضمن التركيز على تحقيق النتائج التالية: (1) (1) تتمية كفايات الطلاب. (r)

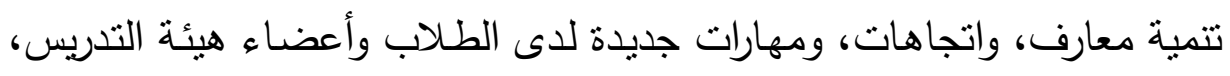

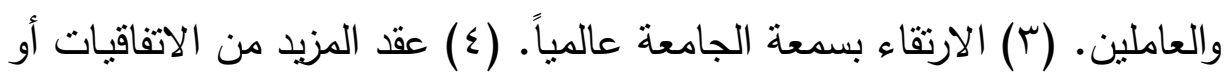

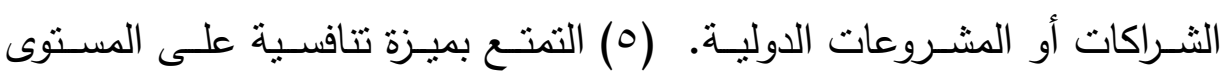

$$
\text { العالمي. }
$$

ج- مدخل الأسباب والمبررات Rationales Approach:

ويركز هذا المدخل على المبررات الرئيسية لتدويل الجامعة، بما في ذلك: (1) (1)

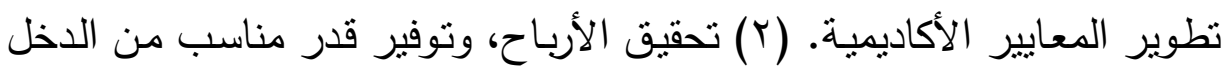

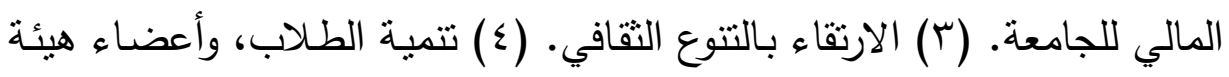

د- مدخل العمليات: Processes Approach

ويتضمن هذا المدخل لتدويل مؤسسـات التعليم العالي القيام بعمليات منتوعـة الغرض منها هو إضفاء البعد الدولي على وظائف التدريس، والتعلم، والبحث العلمي، وخدمة المجتمع الملقاة على كاهل المؤسسات الجامعية المختلفة. 


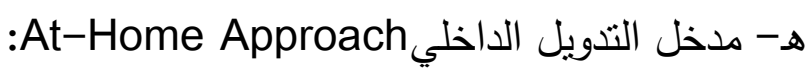
ويتضمن هذا المدخل لتدويل مؤسسات التعليم العالي إقامة ثقافة أو توفير مناخ مناسب داخل البيئة الجامعية يرتقي ويدعم الفهم الدولي أو القائم على التعددية التقافية مع التركيز على الأنشطة الداخلية المطبقة داخل الحرم الجامعي.

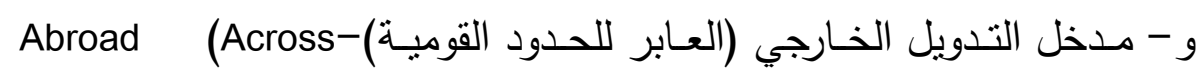
:Border) Approach تقديم خدمات تعليميـة عابرة للحدود القوميـة ببلدان أخرى باستخدام مجموعـة

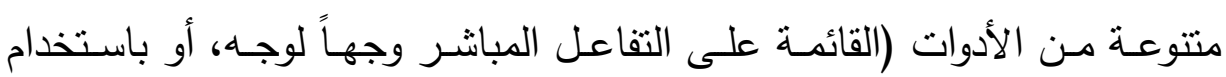
أدوات التعليم الإلكتروني، والتعلم عن بعد) فضلاً عن الاستعانة بعدة استراتيجيات

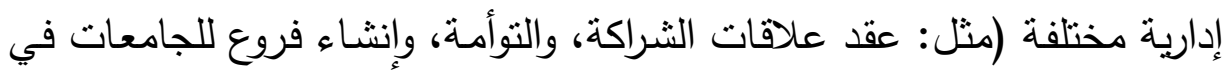
الخارج).

\section{ثالثثاً: تصنيف "تثان وديموك" لمداخل تطيق تدويل التعلم العالي:} قدم "تثان وديموك" (Chan \& Dimmock, 2008) إطار عمل مقترح لتدويل الجامعات يضم ثلاثتة نماذج في ضوء دراسـة الحالة التي أجرياهـا لجامعتين:

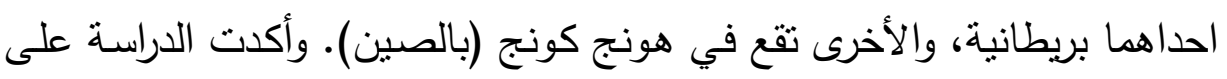

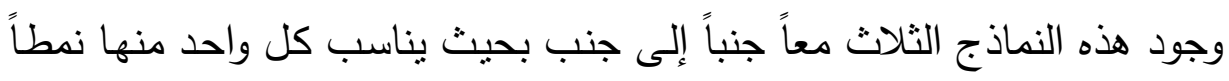

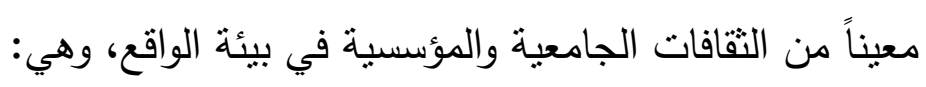

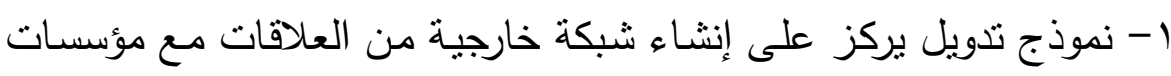

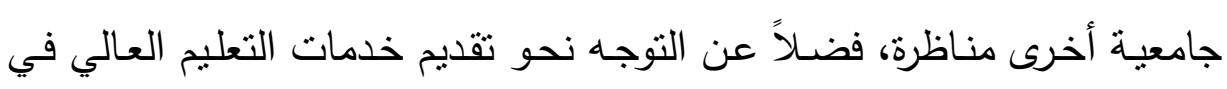

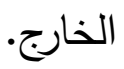

ץ- نموذج تدويل يركز على إضفاء الطابع الدولي على المؤسسات الجامعية

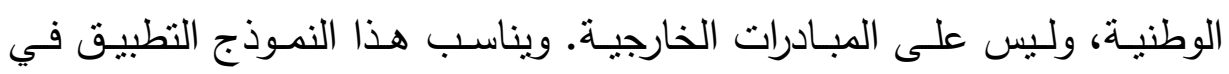
البلدان التي تتمتع بمستوى أقل من التقدم، والتي تحتاج بشدة للتحول إلى دول ولى قومية. 
r- نموذج تدويل ذو صبغة كونية برتبط بالبلدان التي تتوافر بها أعداد كبيرة

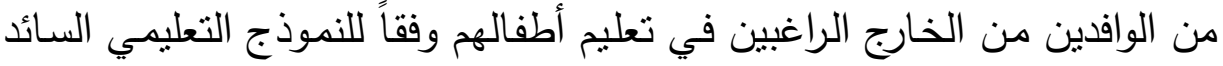

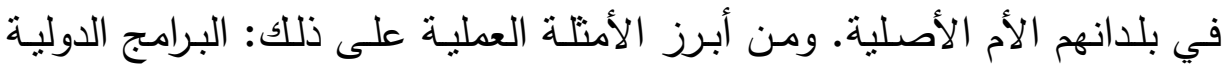
لمنح شهادة البكالوريا.

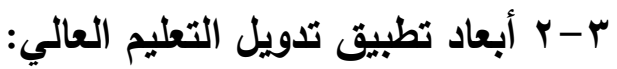
توجد أربعة أبعاد رئيسية لتطبيق تدويل التعليم العالي وذلك وفقاً لما تفيد بـه مراجعة التجارب والخبرات الدولية والتي يمكن عرضها على النحو التالي:

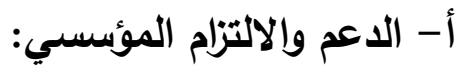
ويعـد أداة رئيسـية لتطـوير جهـود ومبـادرات التـدويل المطبقـة على مسـتوى

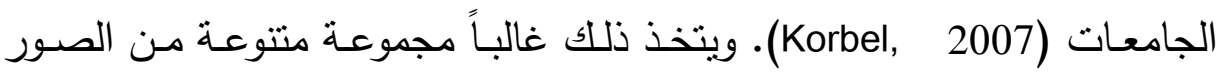
والأشكال من قبيل ما يلي:

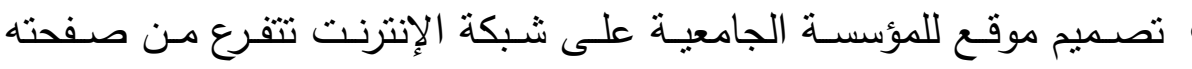
الرئيسية العديد من الروابط التشعبية التي تصل المستخدم ببرامج الجامعة في التدويل.

إجراء دراسـات علميـة تركز على إبـراز نظـرة الأدبيـات السـابقة إلى عمليـة التدويل. التركيز علـى الارتقـاء بالمخرجـات الدوليـة لـتعلم الطـلاب علـى المسـتوى المؤسسي. تشـكيل لجـان أو فـرق عمـل على مسـتوى الجامعـة للإشـراف على متابعـة جهودها في التدويل. إعداد خطط استراتيجية مكتوبـة ومنفصلة لدفع عجلة التدويل على المستوى المؤسسي. الإثـارة إلى التدويل كأحد الأولويات الخمس الاستراتيجية الكبرى في بيـان رسالة الجامعة. 
•قييم المؤسسـة الجامعيـة بشكل رسمي لمدى التقدم الذي تحرزه عملياً على طريق التدويل (Green et al., 2008). r- المبادرات والبرامج الأكاديمية والأنشطة الناصفية:

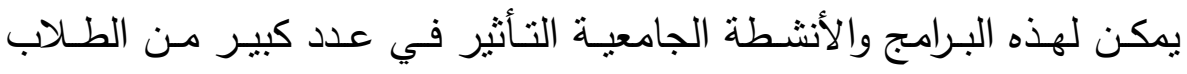

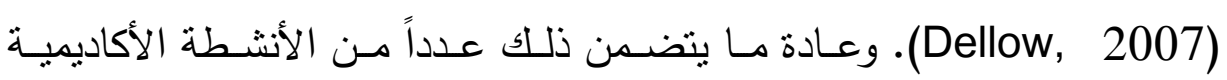
المنتوعة من قبيل ما يلي: الوفاء بمتطلبات دراسـة اللغات الأجنبية- سواء بغرض الالتحاق أو التخرج من الجامعة. دراسة مناهج ومقررات دراسية ذات صبغة دولية. • الفرص المتاحة أمام الطلاب للدراسة بالخارج. • المنـاهج والبرامج الدراسية التي تتيحها الجامعة بمشـاركة مؤسسـات أكاديميـة

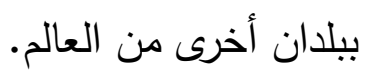
•دعوة أعضاء هيئة التدريس الأجانب كضيوف شرف على المؤنتمرات والندوات الأكاديمية أو البحثية باستخدام مؤنمرات الفيديو (الفيديوكونفرانس)، أو عبر الوبر شبكة الإنترنت. تقـيم الجامعـة لأنشـطة وفعاليـات غيـر صـفية ذات صـبغة دوليـة للطـلاب

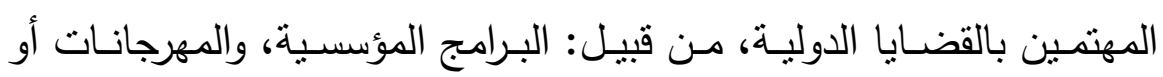
الاحتفالات والمسابقات الدولية (Green et al., 2008). r- السياسات والفرص المتاحة لتدويل أعضاء هيئة التدريس:

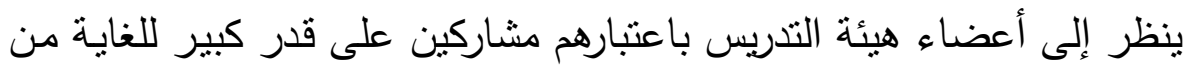

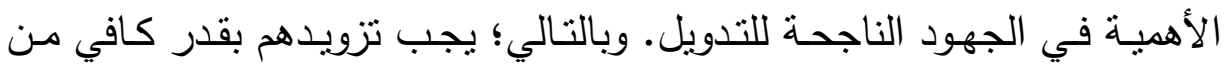

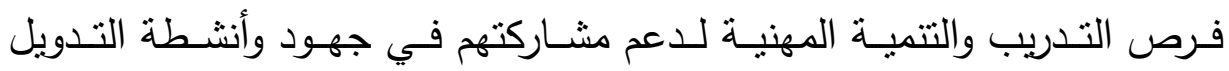
(Raby, 2007). وعادة ما يتضمن ذللك في إطاره استثمار المؤسسة الجامعية فيما يلي: 
• تمكين أعضاء هيئة التدريس من السفر للخارج للمشاركة في أنشطة التعليم،

$$
\text { والبحث العلمي. }
$$

• قيادة الطلاب المشاركين في البرامج الأكاديمية للجامعة في الخارج.

المشاركة في أنشطة التتمية المهنية المرتبطة بالتدويل.

•تمية الخبرات الدولية لأعضاء هيئة التدريس.

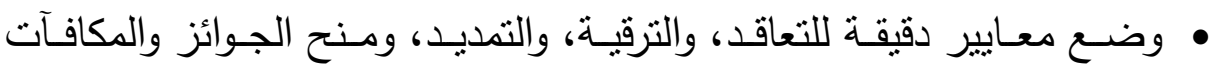

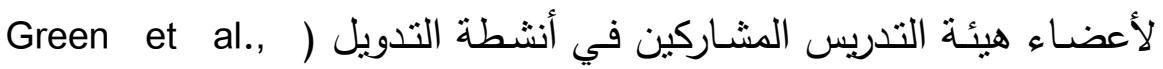

\section{ع- الطلاب الأجانب: International Students}

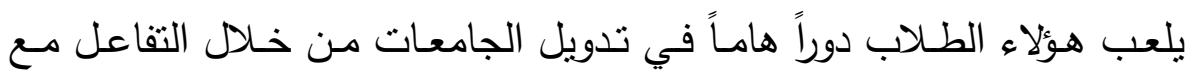
غيرهم مـن الطـلاب الآخرين، وأعضـاء هيئة التدريس، والعـاملين بالجامعـات.

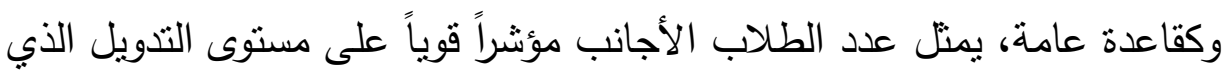
وصلت إليه المؤسسة الجامعية (Hser, 2005).

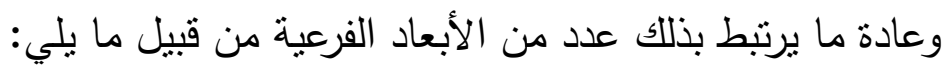

$$
\text { • • معدود استقطاب التحاق الطلاب الأجانب. }
$$

برامج وخدمات تقديم الدعم الأكاديمي لهؤلاء الطلاب.

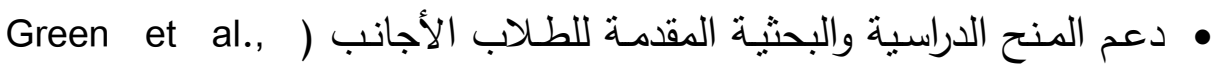
. (2008

كمـا يشـل ذلكـ- أيضـاً - الفرص المتاحـة لـ "الدراسـة بالخـارج" التي يعرفها

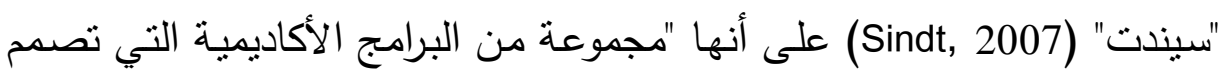

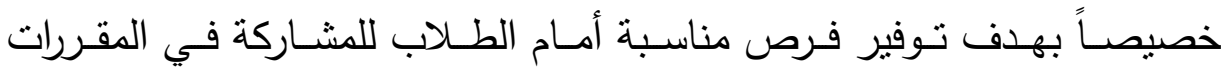

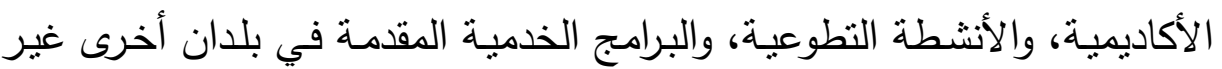
تللك الموجودة في بلد المنشأ أو الإقامة الدائمة للطالب. 


\section{r - r مراحل ومتطلبات تدويل الجامعات:}

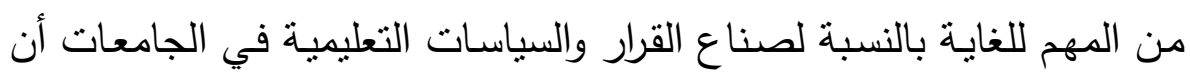

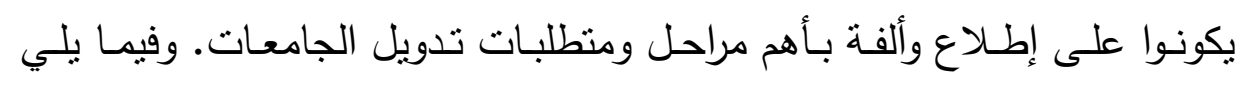
عرض لبعض من النماذج العالمية في تصنيف مراحل تدويل الجامعات. أ- نموذج شورمان لمتطلبات تدويل الجامعات:

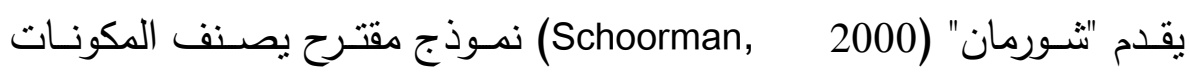

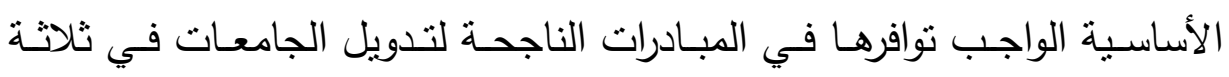
محاور رئيسية متكاملة تضم ما يلي: الواني الركيزة الأساسية للتدويل Core: وتضــ العناصـر الرئيسية الواجب نوافرهـا

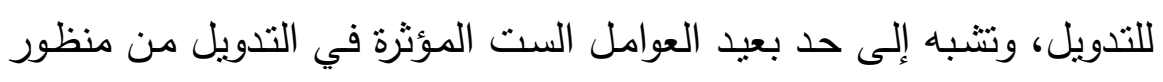

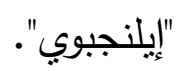

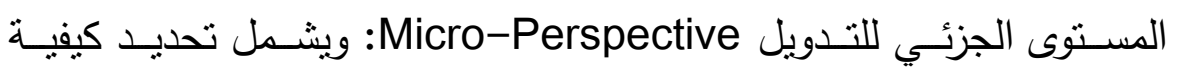

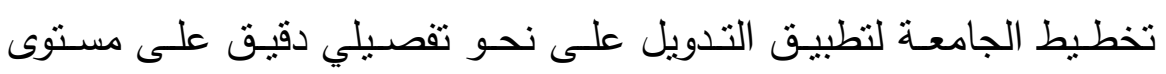
الإدارات والوحدات النتظيمية الفرعية المختلفة.

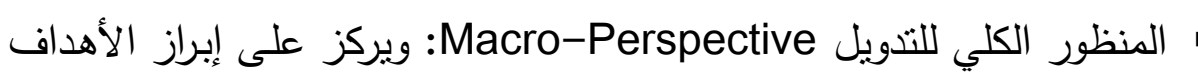
الأكثر عمومية وشمولاً لعملية التدويل، وكيفية الربط بين المكونات المختلفة للمنظومة الجامعية بما يساهم في تحقيق أهدافها المنشودة من وراء التدويل. أ- نموذج "نايت"( ؟ 9 1 ) ) لدورة مراحل وخطوات تذويل الجامعات:

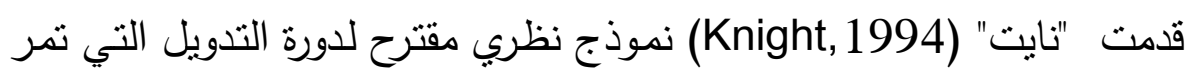

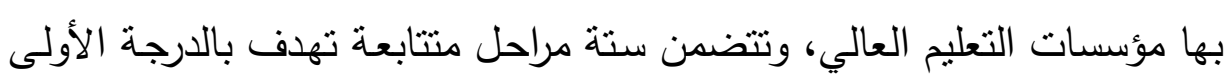

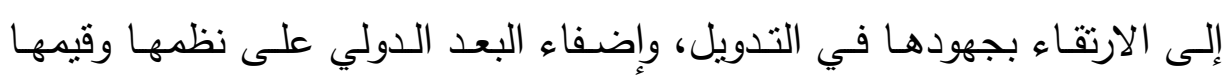

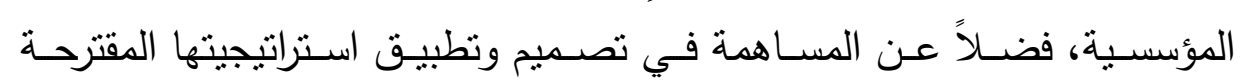
للتذويل. 
ويؤكد النمـذذج على قدرة الجامعات على ترجمـة التزامها بالتدويل إلى خطـة

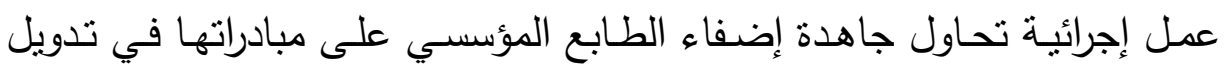
النظم، والممارسـات، والقيم الجامعيـة المختلفـة مـن منظور دولهي عبـر المـرور

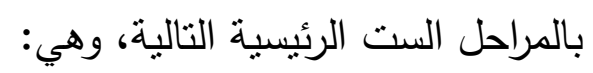
الوعي Awareness: الوعي بالحاجة إلى التدويل، وأهدافه المنشودة، وفوائده

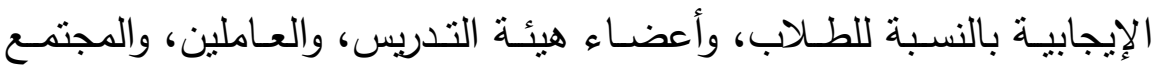
ككل. هالالنزام Commitment، ويشـل ذلك: التزام أعضـاء الإدارة العليـا، وفـرق

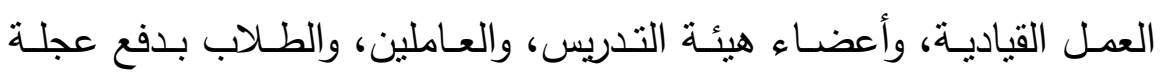
التدويل. التخطيط Planning، ويشـمل ذلك: تحديـ الاحتباجـات والمـوارد المطلوبـة، وصـياغة الأهـداف والأولويـات، واختيــار الاسـتراتيجيات المناسـبة لتـدويل الجامعة.

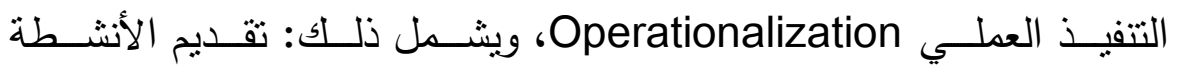
والخدمات الأكاديميـة ذات الصلة، والأخذ بعين الاعتبار العوامل التتظيمية

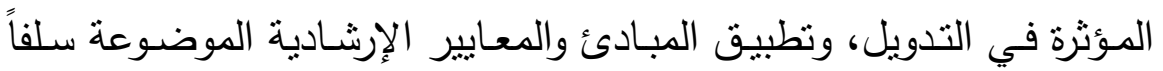
لتدويل الجامعة. المراجعة والتقويم Review، ويشمل ذللك: تقييم وتعزيز جودة تدويل الجامعة،

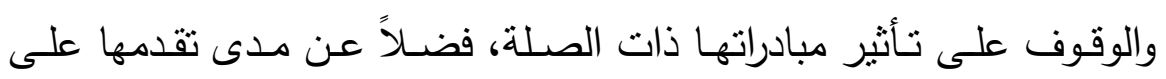
طريق النطبيق الفعال لاستراتيجية التدويل. هeinforcement التعزيـز واللدعم المسـتمر ويشـمل ذللك توفير الحـوافز ، والمكافئات، والتقدير ، والجوائز لأبرز المشاركين في جهودالجامعة للتدويل.

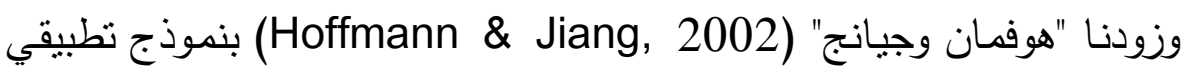

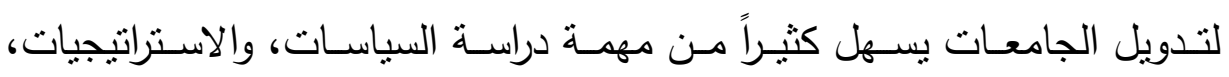


والخطوات الإجرائية المستخدمة في التدويل، فضـلاً عن تحديد الوسـائل الأكثر فاعلية في بناء علاقات التعاون والثراكة الدولية بين مؤسسات التعليم العالي. rيستتد تقييم جهود ومبادرات تدويل مؤسسات التعليم العالي إلى عدد من معايير

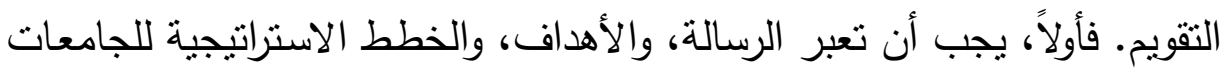
عن التزامها الواضح بالتعليم الدولي، إضـافة إلى توفير الجامعات للبنى، والموارد

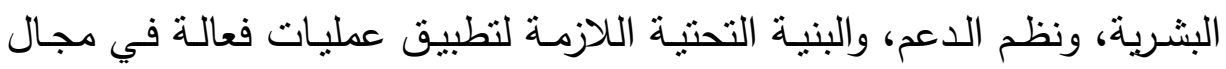
التدويل (Ashizawa, 2006; Connell, 2005; Green, 2007; Knight, 2003). وإضافة إلى ما سبق، يجب أن يتوافر قدر من الاتساق والتناغم بين عمليات

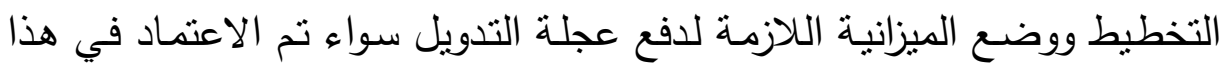

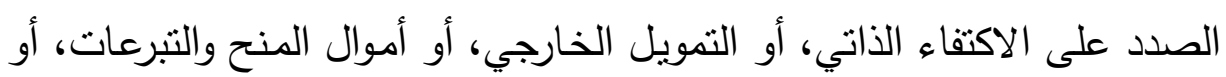
غير ذلك من مصادر التمويل الأخرى للجامعات (De Wit, 2006; Green et al., .(2002; Hser, 2003

كما نجد لدينا- أيضـاً- مؤشرات أخرى هامـة لتقييم فاعلية تدويل الجامعات

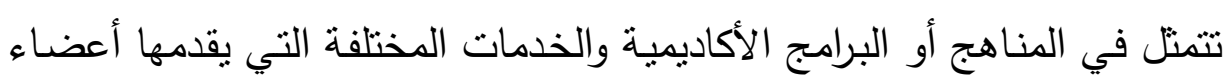
هيئة التدريس بالجامعة عبر التركيز على قياس أبعاد من قبيل مـا يلي: ( )

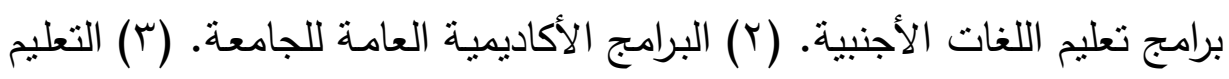

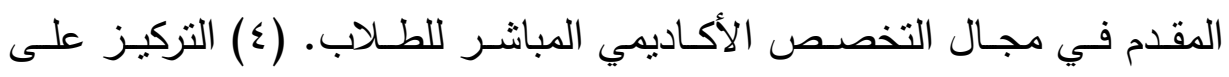
المنظور الدولي في المقررات والمناهج الجامعية ذات الصلة (Altbach, 2002). كما زودنا "لومباردي وزملاؤه" (Lombardi et al., 2003) بنموذج مقترح يضم مجموعة منتوعة من محاور ومؤشرات نقييم جودة وفاعلية تدويل الجامعات يصنفها في إطار خمسة محاور رئيسية تتدرج تحتها تسعة مؤشرات أدائية فرعية

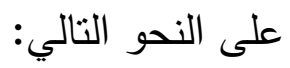


1- فاعلية البحث العلمي Research Competitiveness، ويشمل ذلك مؤشـري: (1) الحجـم الإجمـالي للإنفـاق على أنشـطـة البحـث العلمي

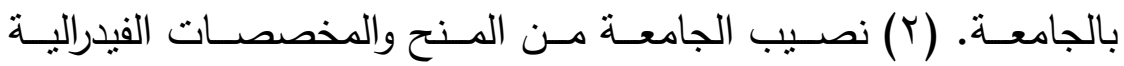
(المقدمة من الحكومة المركزية) لتمويل أنشطتها في البحث العلمي. r- الدعم الخاص Private Support، ويثـمل ذلك مؤشري: (r) أصسول

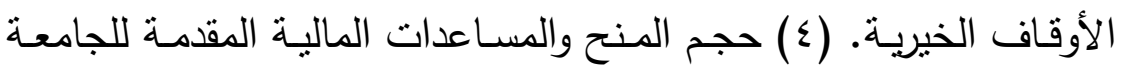
سنوياً. r- تميز أعضاء هيئة التدريس Faculty Distinction، ويشمل ذلك مؤشري: (0) عدد أعضـاء هيئة التدريس الأعضــاء في المؤسســات الأكاديميـة

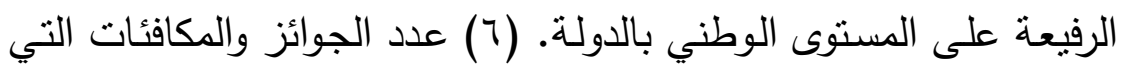

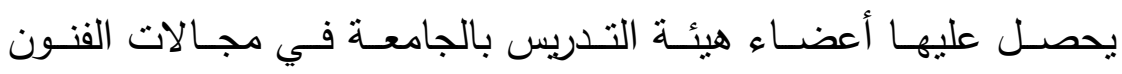

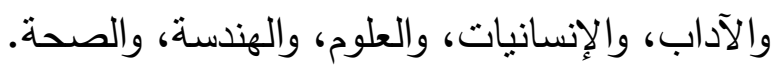

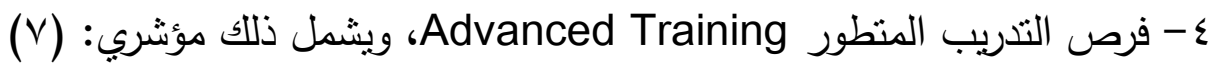
عدد الحاصلين على درجة الدكتوراه. (^) عدد المتقدمين للحصول على مروني درجات ما بعد الدكتوراه- وبخاصة في تخصصي العلوم، والهندسة. ه- جودة التعليم الجامعي Undergraduate Quality، ويشمل ذلك المؤشر ولثراه التالي: (9) متوسط درجات التحصيل الدراسي (GPA) للطلاب الجدد في عامهم الجامعي الأول. توصيات البحث: في ضـوء مـا أسفر عن البحث الحـالي من نتائج، يقدم الباحث التوصيات التالية:

تطبيق المقررات المفتوحة كثيفة الالتحاق (MOOC) في الجامعات المصرية كآلية رئيسية لتطبيق مدخل تدويل التعليم العالي وذلك من خلال تقديم سلسلة من المقررات المفتوحة والتي تتتـاول موضوعات خاصـة بالتعلم مدى الحياة 
من قبيل: التتور الرقمي، ومهارات القرن الحادي والعثرين، والتربية الوالية وغيرها من المواضيع التي يجب التدريب عليها للعيش في القرن الحالي.

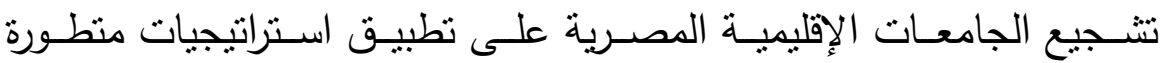
لاستقطاب مزيد من الطلاب الأجانب والطلاب الدوليين للاراسة بها بمراحل ما قبل التخرج والدراسات العليا. العـل على إنثــاء فـروع في بعض الــول الإفريقيـة والعربيـة للجامعـات

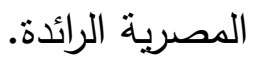

تبني نظام موحد في تقييم الجامعات المصرية في ضوء المؤشرات العالمية بما يمنح هذه الجامعات ميزة تتافسية على المستوى العالمي.

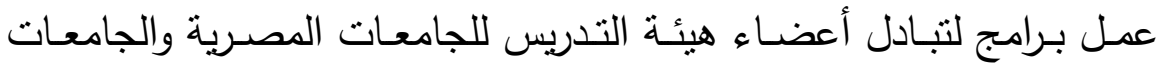
الأجنبية بهدف استقطاب كفاءات متميزة في بعض التخصصات التي تفتقر إليها الجامعات المصرية. العمل على إنشـاء قاعدة البيانات تتضمن تقديم ملخصـات للبحوث العربيـة

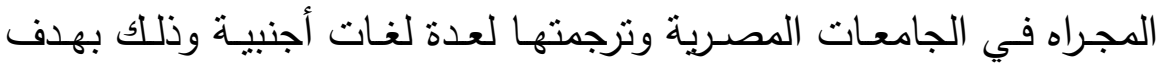
مشاركة المعارف المتجه في الجامعات المصرية على المستوى العالمي.

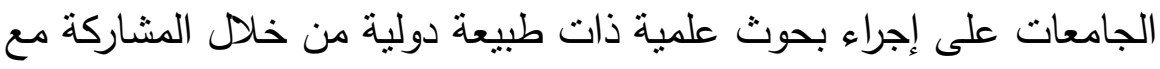
الجامعات والمؤسسات الأجنبية والدولية.

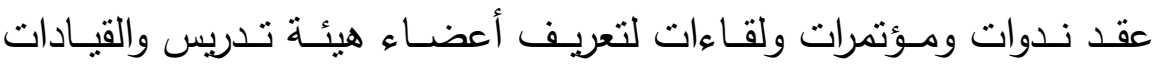
الجامعيـة بأهميـة تدويل التعليم العـالي وسبله واستراتيجيات تطبيقهـ والمزايـا المتحققة من وراءه بالنسبة له وبالنسبة للجامعة.

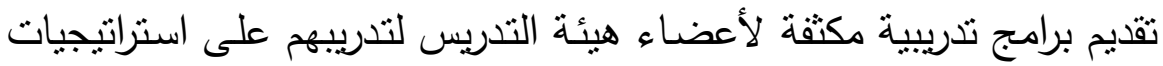
وتطبيق تدويل التعليم العالي بما يجعلهم مؤهلين للمشاركة في تطبيق مثل هن هذه الاستراتيجيات. 
توظيف الثبكات الاجتماعية ووسائل التواصل الاجتماعي كمدخل للتواصل بين الجامعات والمجتمع الدولي بما يسهم في تفعيل الجهود تدويل التعليم

$$
\text { البحوث المقترحة: المصري. }
$$

استتاداً إلى ما تقدم، أقترح إجراء البحوث والدراسات التالية:

إجراء دراسة ميدانية مسحية لرصد واقع تطبيق مداخل تدويل التعليم العالي المطبقة حالياً وذللك في بعض الجامعات ومؤسسات التعليم العالي المصرية. دراسـة ميدانيـة لاتجاهـات قيادات تعليميـة بمصر نحو تبنـي وتطبيق تدويل التعليم والعوامل المؤثرة على هذه الاتجاهات.

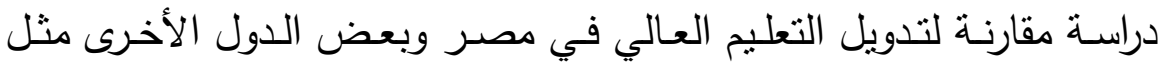
الولايات المتحدة، والمملكة المتحدة، والصين، وكندا.

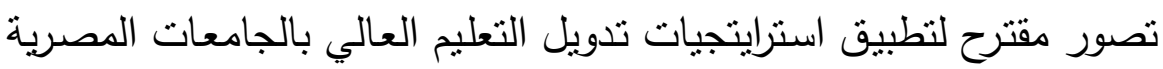
في ضوء الخبرات العالمية المعاصرة. •منطلبات ومعوقات تطبيق تدويل التعليم العالي في الجامعات المصرية من وجهة نظر أعضاء هيئة التدريس والقيادات الجامعيـة: دراسـة وصفية لتئية

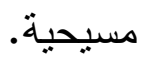
متطلبـات تطبيق تدويل التعليم العـالي مـن وجهة نظر عينـة مـن الخبـراء والمتخصصين. • دراسة تاريخية لتدويل التعليم العالي بالجامعات المصرية: دراسة معتمدة على تحليل الوثائق. دراســة تحليليـة لأهـم نظريـات تـدويل التعلـيم العـالي ومضــامينها بالنسـبة لاستراتيجيات وآليات تطبيق تدويل التعليم بالجامعات المصرية. 


\section{قائمة المراجع}

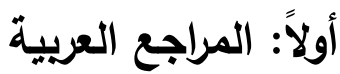

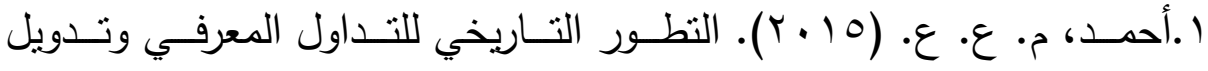
الجامعات .مجلة القراءة والمعرفة -مصر ، ع. • 17 ، 222 - 201. r.العنـزى، س. ب. ع.، و الـدويش، ع. ا. ب. س. (10 • ب). تطـوير تـدويل

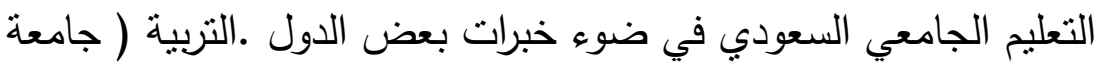

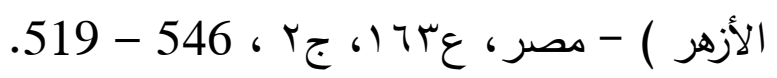

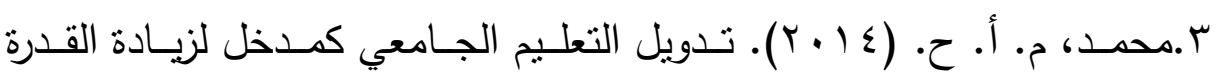

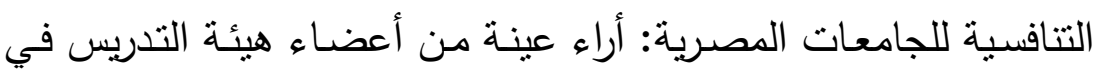

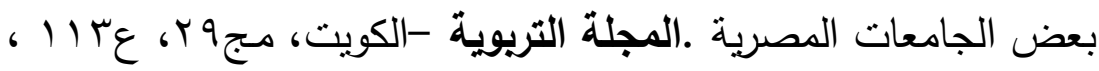

$$
.141-218
$$

ـ .محمـود، س. ط. ( . . ب). الاتجـاه نحسو تـدويل التعلـيم العـالي: العوامـل

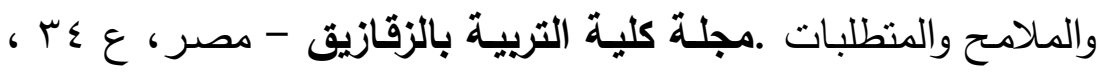

$$
.65-102
$$

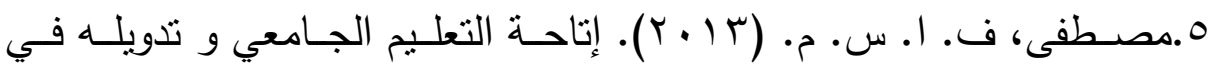

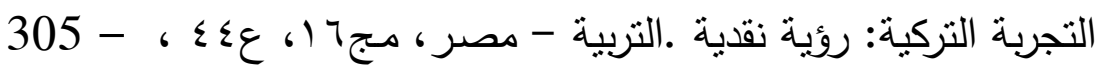

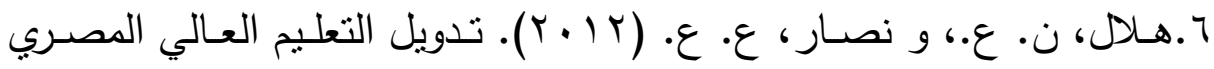

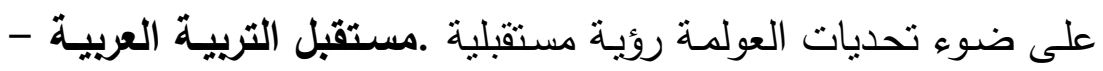

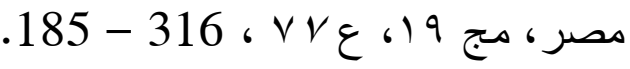

$$
\begin{aligned}
& \text { ثانياً: المراجع الأجنبية }
\end{aligned}
$$

1.Adams, T. (2007). The development of international education in Australia: A framework for the future. Journal of Studies in International Education, 11, 410-420. 
2.Altbach, P.G., \& Knight, J. (2007). The internationalization of higher education: Motivations and realities. Journal of International Studies, 11, 290-305.

3.Ashizawa, S. (2006). Developing evaluation criteria to assess the internationalization of universities. Paper Presented at the meeting of NAFSA: Association of International Educators, Montreal-Canada.

4.Avila, J.G. (2007). The process of internationalization of Latin American higher education. Journal of Studies in International Education, (11) 400-409.

5.Barker, C. (2000). Education for International Understanding and Global Competence. New York, NY: Carnegie Corp.

6.Bruch, T., \& Barty, A. (1998). Internationalizing British higher education: Students and institutions. In P. Scott (Ed.), The Globalization of Higher Education (pp. 18-31). London, UK: SRHE \& Open University Press.

7.Callan, H. (2000). The international vision in practice: A decade of evolution. Higher Education in Europe, 25 (1), 15-23.

8.Carnoy, M., \& Rhoten, D. (2002). What does globalization mean for educational change: A comparative approach? Comparative Education Review, 46 (1), 1-9.

9.Chan, W.Y., \& Dimmock, C. (2008). The internationalization of universities: Globalist, internationalist and translocalist models. Journal of Research in International Education, 7 (2), 184-204.

10.Cornwell, G.H. (2001). Educational and the hegemony of market values: Privilege, practically and citizenship. Liberal Education, 87 (3), 6-13.

11.De Wit, H. (2002). Internationalization of Higher Education in the United States of America and Europe: A Historical, Comparative, and Conceptual Analysis. Westport, CT: Greenwood.

12.Deem, R. (2001). Globalization, New Managerialism, Academic Capitalism and Entrepreneurialism in universities: Is the local dimension still important? Comparative Education, 37 (1), 7-20.

13.Deetman, W.J. (1996). Opening address. In (OECD Documents). Internationalization of Higher Education (pp. 31-33). Paris, France: OECD, Center for Educational Research and Innovation.

Doi : 10.12816/0051209 
14.Dellow, D.A. (2007). The role of globalization in technical and occupational programs. New Directions for Community Colleges, 138, 39-45.

15.Dellow, D.A., \& Romano R.M. (2009). Technological change, globalization, and the community college. Occupational Outlook for Community College Students, 146, 11-19.

16.Green, M., \& Shoenberg, S. (2006). Where Faculty Live: Internationalizing the Disciplines. Washington, DC: American Council on Education.

17.Green, M.F., Luu, D., \& Burris, B. (Eds.). (2008). Mapping Internationalization on U.S. Campuses. Washington, DC: American Council on Education.

18.Hoffmann, E., \& Jiang, XP. (2002). New Zealand and China: A case study of internationalization in New Zealand universities. Proceedings of NZARE Conference 2002. Massey University, Palmerston North-New Zealand.

19.Horn, A.S., Hendel, D.D., \& Fry, G.W. (2007). Ranking the international dimension of top research universities in the United States. Journal of Studies in International Education, $11(3 / 4), 330-358$.

20.Hser, M.P. (2005). Campus internationalization: A study of American universities' internationalization efforts. International Education, 55 (1), 35-48.

21.Huang, F. (2007). Internationalization of higher education in the developing and emerging countries: A focus on transnational higher education in Asia. Journal of Studies in International Education, 11, 421-430.

22.Korbel, L.A. (2007). In union there is strength: The role of state global education consortia in expanding community college involvement in global education. New Directions for Community Colleges, 138, 47-55.

23.Levin, J.S. (2001). Public policy, community colleges, and the path to globalization. Higher Education, 42 (2), 237-262.

24.Levin, J.S. (2007). Missions and structures: Bringing clarity to perceptions about globalization and higher education in Canada. Higher Education, 37 (4), 377-399.

25.Lombardi, J.V., Capaldi, E.D., Reeves, K.R., Craig, D.D., Gater, D.S., \& Rivers, D. (2003). The Top American Research Universities: An Annual Report from the Lombardi Program on Measuring University Performance. Miami, FL: University of Florida Press. 
26.Magrath, P.S. (2000). Globalization and its effects on higher education beyond nation state. Higher Education in Europe, 25 (2), 251-258.

27.Marquardt, M.J. (1999). The Global Advantage: How World-Class Organizations Improve Performance through Globalization. Houston, TX: Gulf.

28.McCarthy, J. (2007). A roadmap for creating the global campus. Chronicle of Higher Education Review, 53 (43), 12-23.

29.McMurtrie, B. (2007). The global campus: American colleges connect with the broader world. The Chronicle of Higher Education, 53 (26), 37-45.

30.Mestenhauser, J.A. (2000). Missing in action: Leadership for international and global education for the $21^{\text {st }}$ century. In L.C. Barrows (Ed.), Internationalization of Higher Education: An Institutional Perspective (pp. 23-62). Bucharest, Romania: UNESCO/CEPES.

31.Mestenhauser, J.A. (2002). In search of a comprehensive approach to international education: A systems perspective. In $\mathrm{W}$. Grünzweig \& N. Rinehart (Eds.), Rockin' in Red Square: Critical Approaches to International Education in the Age of Cyber-Culture (pp. 165-213). Münster, Germany: LIT.

32.Qiang, Z. (2003). Internationalization of higher education: Towards a conceptual framework. Policy Futures in Education, 1 (2), 248-270.

33.Sadlak, J. (1998). Globalization and concurrent challenges for higher education. In P. Scott (Ed.), The Globalization of Higher Education (pp. 100-107). London, UK: SRHE \& Open University Press.

34.Schoorman, D. (2000). How is Internationalization Implemented? A Framework for Organizational Practice. Washington, DC: ERIC Document Reproduction Service. (No. ED444426).

35.Sentürk, I. (2008). The expected and observed effects of globalization on teaching-learning processes on colleges of education: The views of educational faculty. Kuram ve Uygulamada Egitim Bilimleri, 8 (1), 217-224.

36.Sindt, P.E. (2007). Internationalization and higher education: Understanding the impact of short-term study abroad. Ed.D. dissertation, Arizona State University, United States-United States.

37.Stromquist, N.P., \& Monkman, K. (2000). Defining globalization and assessing its implications on knowledge and education.

Doi : 10.12816/0051209 
In N.P. Stromquist \& K. Monkman (Eds.), Globalization and Education: Integration and Contestation Across Cultures (pp. 3-25). Lanham, MD: Rowman \& Littlefield Publishers, Inc.

38.Sutton, M. (2005). The Globalization of multicultural education. India Journal of Global Legal Studies, 12 (1), 97-108.

39.UNESCO. (1998). Higher Education in the Twenty-First Century: Vision and Action. Paris, France: UNESCO.

40.Vestal, T.M. (1994). International Education: Its History and Promise for Today. Westport, CT: Praeger.

41.Welch, A. (2002). Going global? Internationalizing Australian universities in a time of global crisis. Comparative Education Review, 46 (4), 433-471. 
الاتجاهات العالمية المعاصرة في تدويل التعليم العالي دراسة تحليلية وصفية د.عصام جمال سليم غانم 